
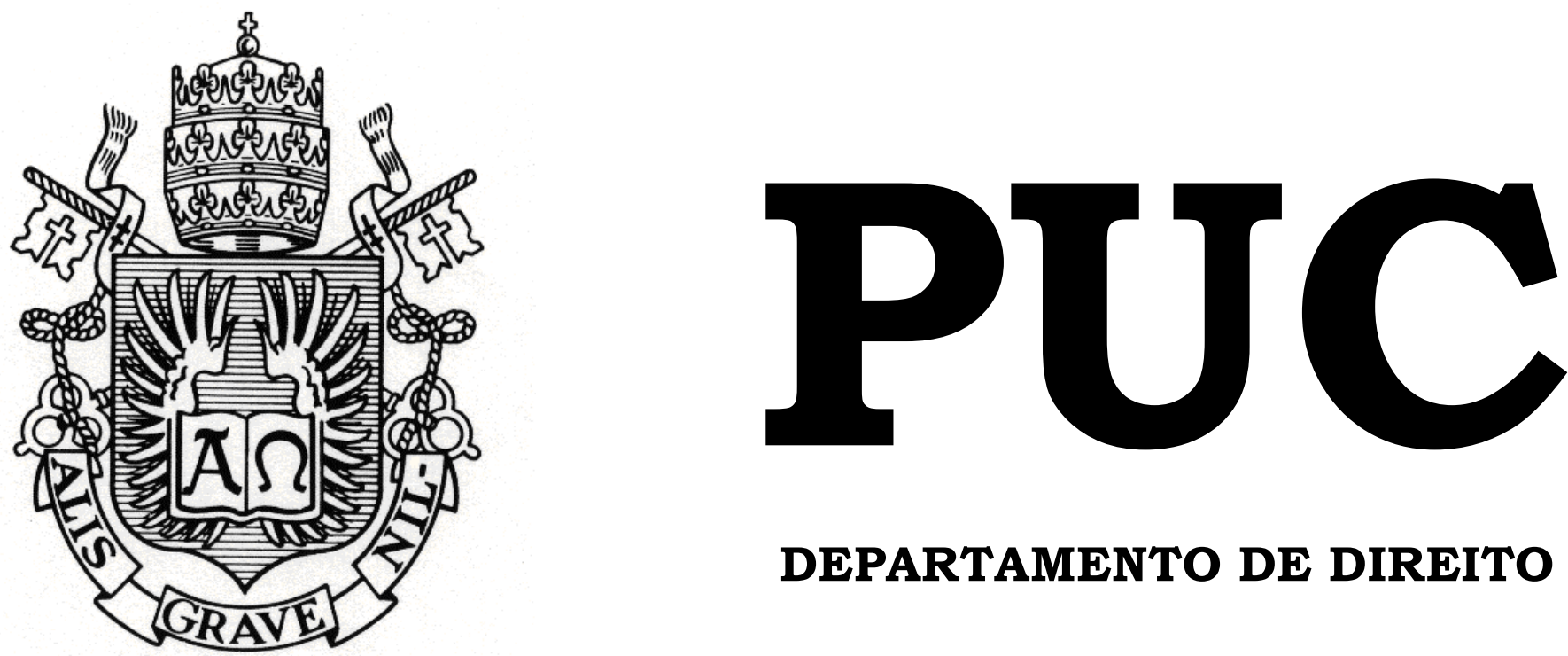

DEPARTAMENTO DE DIREITO

A Extensão dos Efeitos da Cláusula de Arbitragem para Partes Não Signatárias

por

João Marçal Rodrigues Martins da Silva

ORIENTADOR: Lauro Gama Jr.

2010.2

PONTIFÍCIA UNIVERSIDADE CATÓLICA DO RIO DE JANEIRO

RUA MARQUÊS DE SÃO VICENTE, 225 - CEP 22453-900

RIO DE JANEIRO - BRASIL 


\title{
A Extensão dos Efeitos da Cláusula de Arbitragem para Partes não Signatárias
}

\author{
por \\ JOÃO MARÇAL RODRIGUES MARTINS DA SILVA
}

Monografia

apresentada

ao

Departamento de Direito da Pontifícia Universidade Católica do Rio de Janeiro (PUC-Rio) para a obtenção do Título de Bacharel em Direito.

Orientador: Lauro Gama Junior 
A meus pais, pela incansável dedicação ao seu filho.

Aos meus avós, pela acolhida.

Aos meus tios, por sempre me incentivarem em tudo.

Aos amigos, por sempre se fazerem presentes. 


\section{AGRADECIMENTOS}

O ano é 2006. Eu tinha acabado de me formar no colégio e não sabia o que esperar da faculdade. Chega o primeiro dia de trote e estendo a mão a um outro calouro, como eu, cumprimentando-o e conversando sobre aquela nova fase em nossas vidas. Daquele dia em diante, no decorrer do trote, passo a conversar com mais alguns amigos que merecem atenção nestes agradecimentos.

O calouro acima é Adriano Carneiro, um grande amigo que a PUC-Rio me deu. Logo em seguida, conheci outros amigões que levo da faculdade, para o resto da minha vida, são eles: Bernardo Doutel, Fábio Werneck, Fernando "Fefê" Moura, Bruno Barreto, Josef Azulay, Hugo Wery, Guilherme Esch (o “pé”), Ana Luiza Mello, Fernanda Soeiro e Renan Aniceto.

Falar desses amigos que a PUC-Rio me deu me faz lembrar tudo que eu passei durante a faculdade. Namoros que começaram e terminaram; viagens históricas que ocorreram (vale frisar que eu conheci um dos meus melhores amigos de faculdade durante um dos jogos jurídicos); noites mal dormidas, em virtude de provas; churrascos, aniversários...

O tempo se passou e chegou o momento em que era necessário estagiar. Aquele mal que me parecia necessário, me fez chegar à maior escola da minha vida: o Machado, Meyer, Sendacz e Opice Advogados. O "MMSO" me ensinou não só o Direito na prática, mas me mostrou a importância de valores como perseverança, lealdade e confiança. São mais de dois anos de aprendizado e amadurecimento profissional.

Nessa esteira, não há como não citar os nomes de: Leonardo Corrêa, o exemplo de

profissional a ser seguido, não só por seu caráter e por seu notório saber, mas por me 
incentivar e me mostrar a beleza do mundo da dialética e das ferramentas de persuasão. Não tenho vergonha em afirmar que me orgulho em ser seu estagiário; Diego "Ratazana" Galvão, mais que um colega de trabalho, um irmão que a vida me deu; Simone Weber, a quem eu tenho um carinho enorme e que tanto me ajudou; Eliane Leve, sempre simpática e disposta a ajudar; Karin Sanchez, minha companheira de baia e que tem que me suportar todos os dias; e os demais colegas de escritório que fazem a rotina parecer mais leve do que parece, como: Alexandre Lima, Thiago Rabello, Rodrigo Verdini, Rafael Firmo, o ex-estagiário sempre presente nos chopps, e o Prof. Felipe, de inglês, um amigo que considero como integrante do MMSO.

Não poderia deixar de citar o sócio da área, na qual trabalho, Paulo Rogério Brandão Couto, que sempre me incentivou e me apoiou quando mais precisei. Um grande apoio que imediatamente me vem à cabeça foi o subsídio para viajar a Viena, com o Grupo de Arbitragem da PUC-Rio, para participar do Willem C. Vis International Commercial Arbitration Moot, a mais importante competição de arbitragem comercial do mundo.

Por falar nessa viagem, percebo o quanto o Grupo de Arbitragem da PUC-Rio foi importante para o meu aperfeiçoamento acadêmico. Agradeço ao meu orientador e técnico da equipe, Prof. Lauro Gama, insigne (aqui eu posso usar?) professor, árbitro, advogado e orientador, que tantas vezes se dispôs a ceder sua casa para que a equipe de arbitragem pudesse treinar e redigir os memorandos da competição.

Agradeço também aos integrantes da equipe. Em primeiro lugar, a velha-guarda. Ao Rodrigo Moreira, por sua inestimável ajuda e companheirismo na longa estrada que leva a Viena. Ao Lucas Mendes, minha dupla de oratória na competição, mas, não só isso, outro grande amigo que a vida me deu. Ao Bruno Barreto, já citado anteriormente, mas por fazer 
parte da equipe, merece ter seu nome mais uma vez citado, já que compartilhou das angústias e das preocupações em tornar nossa equipe competitiva.

Cito também o João Vicente DE Assis e os novos integrantes do grupo, que já demonstraram seu valor. Agradeço especialmente à Luiza Bartolo, por sua simpatia e atenção, e à Fabiana Almeida, que foi uma das responsáveis pela qualidade desta monografia, pois além de me emprestar valiosos livros, sempre me ouvia lamentar acerca desta monografia.

Lembro, ainda, de pessoas que conheci no final da faculdade e que já considero amigos de longa data. Nesse sentido, cito "o trio": Patricia Rocco, Ana Beatriz Torós e Alana Mendes.

Por fim, como não poderia deixar de ser, agradeço à minha família. Ao meu pai, que tantas caronas me deu para que eu fosse ao escritório redigir esta monografia e que nunca mediu esforços pelo meu sucesso e pela minha educação (destaco que sempre que perguntara se poderia comprar um livro, obtinha um sim como resposta). À minha mãe, que sempre me apoiou e servia meu jantar quando eu chegava do escritório de madrugada, cansado, depois de horas de pesquisa... Aos meus tios, que se mostraram presentes neste ano tão difícil e complicado. Saber, mais do que nunca, que posso contar com eles, me deixa muito feliz.

E aos meus velhos (porém bons) amigos que souberam (?) entender minha ausência, em virtude da complexidade do presente estudo.

Nesse sentido agradeço à: Matheus Almeida, Bruno Barbosa, Eric Gaia, Matheus Fierro, Pedro Coutinho, Felipe Miranda, Eduardo Silveira, Camila Viana, Bernardo Carnevale, Brenno Carnevale, Bruno Hwang, Rafael Navega, Felipe Pereira, Henrique Pimenta, Raphael Diniz, Jovi, Rogério Sganzerla, Tamiris Ferreira, Luiza Martins, Bruna 
Bataglia, dentre outros que me fizeram perceber que a caminhada pode ser longa, mas nunca se está sozinho.

A todos vocês, o meu sincero muito obrigado. 
"De tudo ficaram três coisas:

A certeza de que estamos começando, A certeza de que é preciso continuar A certeza de que podemos ser interrompidos antes de terminar

Fazer da interrupção um caminho novo, Fazer da queda um passo de dança, Do medo uma escola, Do sonho uma ponte, Da procura um encontro, [Da derrota, um incentivo]

E assim terá valido a pena existir!" (Fernando Sabino) 
Trata-se de trabalho monográfico que visa apresentar os contornos da extensão dos efeitos da cláusula de arbitragem para partes não signatárias. Para tanto, procedeu-se à análise da evolução do paradigma da referida extensão no Direito privado internacional (com ênfase no Direito americano e no Direito francês, que são representativos das principais tradições jurídicas contemporâneas: a common law e a civil law, respectivamente) e no Direito brasileiro.

\section{PALAVRAS-CHAVE}

Arbitragem - extensão dos efeitos da cláusula compromissória - desconsideração da personalidade jurídica - tutela externa do crédito - consentimento tácito - contratos coligados. 


\section{SUMÁRIO DA MONOGRAFIA}

Página

Introdução

10

Capítulo 1 - A regra geral - a não extensão dos efeitos da 15 cláusula de arbitragem para partes não signatárias

1.1 O princípio da relatividade dos contratos (ou "privity of 17 contracts")

1.2 A necessidade da cláusula de arbitragem ser celebrada por 18 escrito

1.3 O requisito do consentimento das partes - um dos pilares da arbitragem

Capítulo 2 - A possibilidade de extensão dos efeitos da cláusula compromissória no Direito comparado

2.1 A teoria do "Group of Companies" e o caso Dow Chemical 27

2.1. A doutrina do "Alter Ego", "Piercing the Corporate Veil" ou 31 "Disregard of legal entity"

2.2 O "implied consent" 39

2.3 A teoria do "Group of Contracts" ou "Contratos Coligados" 45

Capítulo 3 - A extensão dos efeitos da cláusula de arbitragem 52 para partes não signatárias à luz do Direito brasileiro

3.1 A desconsideração da personalidade jurídica 52

3.2 O consentimento tácito e o caso Trelleborg 57

3.3 Os contratos conexos 62

3.4 A tutela externa do crédito 69

$\begin{array}{ll}\text { Conclusão } & 76\end{array}$

$\begin{array}{ll}\text { Bibliografia } & 78\end{array}$ 


\section{INTRODUÇÃO}

Sento-me para escrever este trabalho monográfico e me pergunto o motivo de escolher o presente assunto e tema. A resposta não me parece difícil. A arbitragem foi uma área que me tirou do marasmo com o qual eu observava o Direito na prática. A possibilidade de trabalhar com resolução de disputas, ferramentas de persuasão e dialética me encantaram de tal forma, que me apaixonei de imediato pela matéria.

Não fosse só isso, tenho o prazer de participar do Grupo de Estudos em Arbitragem e Direito do Comércio Internacional da PUC-Rio - o GEADICI. Este grupo que honrou o nome da PUC-Rio na última edição do Willem C. Vis International Commercial Arbitration Moot, a mais importante competição de arbitragem comercial internacional do mundo (da qual participam mais de duzentas e vinte faculdades de todos os cinco continentes), e que semanalmente se reune para discutir matérias relacionadas à arbitragem.

Quando afirmei que a resposta para escolher o campo de trabalho desta monografia não era tão difícil, não falei apenas por falar. A arbitragem foi sutilmente aparecendo na minha vida acadêmica e profissional, sendo certo que quando me dei conta, já estava a estudar o instituto e todas as suas nuances. A pergunta que vem em seguida é o motivo da escolha do tema abordado neste trabalho monográfico.

Ora, não há dúvidas de que há, em escala global, um crescente número de transações comerciais, seja por motivos financeiros, fiscais ou operacionais. Por vezes, por exemplo, certo país oferece uma diminuição da carga tributária, as leis trabalhistas são mais favoráveis ou, até mesmo, o custo de produção é mais baixo. 
Ao passo que essas transações aumentam, o nível de complexidade de muitas operações também tende a crescer exponencialmente. Seja pela forma como são tratadas (e-mail's, fax, telefone, correspondências, etc.) ou pelas partes envolvidas (diferentes empresas de um grupo econômico, subcontratadas, entes estatais), fato é que muitas vezes existe uma dificuldade em se reconhecer quem realmente faz parte de um contrato.

Antes de enfrentar a problemática de quem é parte em um contrato, é necessário definir alguns conceitos vitais para o entendimento deste trabalho.

Segundo uma perspectiva econômica, contrato é um instrumento de alocação de riscos ${ }^{1}$. As partes pactuam seus deveres e suas obrigações com o objetivo de celebrar um determinado negócio. Dentro do contrato, as partes podem optar por um sistema de resolução de conflitos, com o intuito de solucionar uma eventual disputa.

Nessa esteira, cada vez mais, a arbitragem vem sendo utilizada como meio para resolução destas controvérsias. No universo contratual das grandes transações e do comércio internacional, a arbitragem se tornou o principal método de resolução de disputas ${ }^{2}$.

Percebe-se a importância do instituto em razão de renomadas instituições de arbitragem que anunciam o aumento de suas atividades ano a ano, novos centros de arbitragem que surgem para suprir a demanda deste novo negócio, Estados nacionais que modernizam suas leis para serem considerados incentivadores da arbitragem, escritórios de advocacia que instituíram setores dedicados somente à arbitragem, conferências e

\footnotetext{
${ }^{1}$ Nesse sentido confira-se: FOX, Charles M. Working with Contracts: What Law School Doesn't Teach You. New York City: Practising Law Institute, 2002. p. 3.

${ }^{2}$ Observe-se a lição de: BLACKABY, Nigel et. al.. Redfern and Hunter on International Arbitration. Student Version. Fifth Edition. Oxford: Oxford University Press, 2009. p.1.
} 
seminários que proliferam rapidamente e da atenção que as universidades de Direito vêm dando à arbitragem, reconhecendo-na como uma matéria. ${ }^{3}$

Para se ter uma idéia, há uma estimativa do Conselho Nacional das Instituições de Mediação e Arbitragem (Conima) no sentido de que a arbitragem cresça no mínimo $10 \%$ ao ano e, no futuro, expanda suas áreas de atuação e estabeleça um novo paradigma com o fim da cultura do litígio 4 .

Insere-se nos contratos, assim, uma cláusula de arbitragem, na qual as partes em disputa elegerão árbitros independentes, imparciais e da confiança delas que decidirão acerca de um litígio que venha a surgir. Esta decisão será final e obrigatória perante as partes, afastando a submissão da questão ao Poder Judiciário.

Na precisa lição do professor Carlos Alberto Carmona:

"a arbitragem é uma técnica para a solução de controvérsias através da intervenção de uma ou mais pessoas que recebem seus poderes de uma convenção privada, decidindo com base nesta convenção sem intervenção do Estado, sendo a decisão destinada a assumir eficácia de sentença judicial." 5

Dito isso, é importante salientar que vem aumentando o número de casos em que árbitros e tribunais nacionais (quando a disputa é levada ao Poder Judiciário) são interpelados com a hipótese de uma cláusula de arbitragem, assinada por um indivíduo ou uma empresa, poder ser estendida à partes que não pactuaram a resolução de suas disputas por arbitragem.

\footnotetext{
3 Ibid. p.1.

${ }^{4}$ HENRIQUES, Andréia. Judiciário - Arbitragem cresce 10\% ao ano e ganha espaço nas empresas. Disponível em http://www.conima.org.br/informativo/info03. Acesso em 01 nov. 2010.

${ }^{5}$ CARMONA, Carlos Alberto. Arbitragem e Processo: Um comentário à Lei no 9.307/96. $3^{\text {a }}$ Edição. São Paulo: Editora Atlas, 2009. p. 15.
} 
A linha de pesquisa em que se insere este trabalho tem como objetivo principal, portanto, identificar, analisar e compreender os efeitos da cláusula de arbitragem perante as partes que não assinaram a referida cláusula.

A extensão da cláusula compromissória à partes não signatárias é uma das questões mais complexas e debatidas por juristas, árbitros e advogados no mundo todo. No Brasil, o tema não é amplamente discutido e poucos foram os que enfrentaram devidamente esta questão ${ }^{6}$.

A recente jurisprudência brasileira ${ }^{7}$ permite antever uma posição um pouco mais flexível quanto à possibilidade de se estender os limites da cláusula de arbitragem, baseando-se na manifestação tácita do consentimento das partes em se submeter à arbitragem, mas, mesmo assim, são escassas as decisões que enfrentam o tema.

Diante disso, o objetivo deste projeto é contribuir para a construção teórica e conceitual da possibilidade de extensão da cláusula compromissória, identificando o alcance dos efeitos da inclusão de partes, que não aderiram a convenção de arbitragem, ao procedimento arbitral.

Para tanto, no capítulo um, aborda-se a regra geral, qual seja, a não extensão dos efeitos da cláusula de arbitragem para partes não signatárias. Analisar-se-á a regra geral sob a ótica do princípio da relatividade dos contratos, da necessidade da cláusula de arbitragem ser celebrada por escrito e, por fim, do requisito do consentimento das partes.

\footnotetext{
${ }^{6}$ Como se verá no decorrer do presente trabalho monográfico, poucos autores abordaram sobre a extensão dos efeitos da cláusula compromissória para partes não signatárias. Cite-se, e.g., Pedro A. Batista Martins, Arnoldo Wald, Flávio Pereira Lima e Daniel Calhman.

${ }^{7}$ A esse respeito, analisamos no capítulo 3 o caso Trelleborg (TJ-SP, Apelação n. 267.450.4/6-00 - $7^{\mathrm{a}}$ Câmara de Direito Privado, Rel. Desembargadora Constança Gonzaga, São Paulo, 24 mai. 2006).
} 
O capítulo dois trata da possibilidade de extensão dos efeitos da cláusula compromissória no Direito comparado, com ênfase no Direito francês e no Direito americano, que são representativos das principais tradições jurídicas contemporâneas: a civil law e a common law, respectivamente. Os argumentos estudados são a teoria do "group of companies", a qual engloba a doutrina do "alter ego", "piercing the corporate veil ou "disregard of legal entity" e o caso Dow Chemical, a teoria do "implied consent" e a teoria do "group of contracts" ou "contratos coligados".

No capítulo três, aborda-se a questão da extensão dos efeitos da cláusula de arbitragem para partes não signatárias à luz do Direito brasileiro. O enfoque deste capítulo está na desconsideração da personalidade jurídica, no consentimento tácito e no "leading case" Trelleborg, nos contratos conexos ${ }^{8}$ e na tutela externa do crédito.

Após o exame do Direito comparado e do Direito brasileiro, concluise este trabalho monográfico, apresentando críticas para a extensão dos efeitos da cláusula compromissória para aquelas partes que não assinaram a referida cláusula.

Nas palavras do prof. Carlos Alberto Carmona: "o problema, é claro, não é novo, mas começa agora - com o notável desenvolvimento arbitragem no Brasil - a preocupar a doutrina nacional" ${ }^{9}$. Mãos à obra!

\footnotetext{
${ }^{8}$ Para efeitos deste trabalho monográfico, o termo contratos conexos é sinônimo de contratos coligados. Confira-se, nessa esteira, a lição de Barbosa Moreira: "Se não se reconhecer a unidade contratual, não se fugirá, em todo caso, à caracterização dos contratos como conexos, vinculados ou coligados." (BARBOSA MOREIRA, José Carlos. Unidade ou Pluralidade de contratos: contratos conexos, vinculados ou coligados. Litisconsórcio necessário e litisconsórcio facultativo. 'Comunhão de interesses', 'conexão de causas' e 'afinidade de questões por um ponto comum de fato ou de direito'. Revista dos Tribunais. São Paulo, v. 817, p. 757).

${ }^{9}$ CARMONA, Carlos Alberto. Op. cit., p. 82.
} 


\section{Capítulo 1 - A regra geral - a não extensão dos efeitos da cláusula de arbitragem para partes não signatárias}

Como se demonstrará a seguir, a lei, a doutrina e a jurisprudência, brasileira e em grande parte, a internacional, apontam que a regra vigente é a de que a cláusula de arbitragem não pode ter seus efeitos estendidos a quem não assinou a referida cláusula.

Tal regra decorre precipuamente de três ordens de razão:

(i) o contrato só produz efeitos entre as partes contratantes princípio da relatividade dos contratos (ou "privity of contracts");

(ii) a cláusula de arbitragem deve ser celebrada por escrito; e,

(iii) a arbitragem repousa no consentimento das partes.

\section{Nota prévia: O princípio da autonomia da cláusula de arbitragem}

Antes de adentrar ao princípio da relatividade dos contratos, é imperioso esclarecer o conceito de um outro princípio, qual seja, o da autonomia da cláusula de arbitragem.

Nas palavras de Fouchard, Gaillard e Goldman: "what is traditionally meant by the autonomy of the arbitration agreement is its autonomy from the main contract in which it is found or to which it relates". 10

\footnotetext{
${ }^{10}$ FOUCHARD, Philippe et al.. Fouchard Gaillard Goldman on International Commercial Arbitration. The Hague: Kluwer Law International, 1999. p. 198.
} 
O princípio da autonomia da cláusula de arbitragem ${ }^{11}$ está expresso no caput do art. $8^{\circ}$ da nossa Lei de Arbitragem (Lei 9.307/96). Segundo o mencionado artigo:

“a cláusula compromissória é autônoma em relação ao contrato em que estiver inserta, de tal sorte que a nulidade deste não implica, necessariamente, a nulidade da cláusula compromissória.

Parágrafo único. Caberá ao árbitro decidir de ofício, ou por provocação das partes, as questões acerca da existência, validade e eficácia da convenção de arbitragem e do contrato que contenha cláusula compromissória."

Nessa linha, a jurisprudência nacional é pacífica quanto ao tema. À guisa de exemplo, confira-se excerto da ementa de acórdão do Tribunal de Justiça do Estado do Rio de Janeiro, sob relatoria do Des. Gilberto Rego:

"a cláusula compromissória é autônoma em relação ao contrato em que está incerta, assim perfazendo, em si mesma, um negócio jurídico, cujo destino é indiferente àquele do contrato em que porventura foi estabelecida. Tal autonomia indica que a extinção do contrato principal não induz à ineficácia da cláusula que instituiu a arbitragem como meio de solução pacífica das controvérsias porventura decorrentes das relações regidas pelo mesmo contrato" ${ }^{12}$.

Resta claro, portanto, que a cláusula de arbitragem é um contrato à parte do contrato em que está inserida. Em outras palavras, há dois contratos: o de arbitragem e o principal. Conforme se depreende da lição do co-autor do anteprojeto da Lei de Arbitragem Brasileira, Pedro A. Batista Martins:

"A lei é bastante clara e contundente: a convenção de arbitragem é autônoma em relação ao contrato em que estiver

${ }^{11} \mathrm{O}$ referido princípio também é conhecido como severability, separability, independence ou detachment da cláusula compromissória (Nesse sentido, MARTINS, Pedro A. Batista. Autonomia da cláusula compromissória. Disponível em <http://www.batistamartins.com/artigos>. Acesso em 01 nov. 2010.

12 TJ-RJ, Apelação Cível no 2001.001.28808, Rel. Gilberto Rego, Rio de Janeiro, 30 abr. 2002. No mesmo sentido confira-se também o seguinte julgado: TJ-RJ, Agravo de Instrumento $\mathrm{n}^{\circ}$ 07839/2003, Rel. Ademir Paulo Pimentel, Rio de Janeiro, 29 out. 2003. 
inserta, cabendo ao árbitro decidir as questões acerca da existência, validade e eficácia da convenção de arbitragem e do contrato que contenha a cláusula compromissória" ${ }^{13}$.

Tendo-se em mente o conceito de autonomia da cláusula de arbitragem e que a referida cláusula também é um contrato, cumpre, nesse momento, abordar o princípio da relatividade dos contratos.

\subsection{0 princípio da relatividade dos contratos (ou "privity of contracts")}

A doutrina aponta que segundo o princípio da relatividade dos efeitos contratuais o contrato somente vincula as partes, não beneficiando nem prejudicando terceiros. ${ }^{14}$

Não destoa desse entendimento a lição de Orlando Gomes, que assevera que o "princípio da relatividade dos contratos diz respeito à sua eficácia (...) o que significa que seus efeitos se produzem exclusivamente entre as partes, não aproveitando nem prejudicando terceiros" ${ }^{\prime 15}$. Cite-se ainda as palavras de Carlos Maximiliano, o qual aduz que "as obrigações, em regra, vinculam, apenas, os contratantes e os respectivos sucessores"16.

$\mathrm{Na}$ esfera internacional, o princípio da relatividade dos contratos (ou “privity of contracts") também é amplamente difundido. Observe-se, a esse

\footnotetext{
${ }^{13}$ MARTINS, Pedro A. Batista. Apontamentos sobre a Lei de Arbitragem. $1^{\text {a }}$ Edição. Rio de Janeiro: Forense, 2008. p. 136.

${ }^{14}$ Nesse sentido confira-se: JUNQUEIRA DE AZEVEDO, Antônio. Revista dos Tribunais. Princípios do Novo Direito Contratual e Desregulamentação do Mercado - Direito de Exclusividade nas Relações Contratuais de Fornecimento - Função Social do Contrato e Responsabilidade Aquiliana do Terceiro que Contribui para Inadimplemento Contratual. RT. São Paulo, n.750, p.113-119, abr.1998. No mesmo sentido: TEPEDINO, Gustavo et al.. Código Civil interpretado: conforme a Constituição da República. v. II. Rio de Janeiro: Renovar, 2006. p. 6.

${ }^{15}$ GOMES, Orlando. Contratos. $26^{\mathrm{a}}$ ed.. Rio de Janeiro: Forense, 2007. p. 46.

${ }^{16}$ MAXIMILIANO, Carlos. Hermenêutica e aplicação do direito. Rio de Janeiro: Forense, 1996. p. 261.
} 
respeito, o art. 1.3 dos Princípios do Unidroit ${ }^{17}$, in verbis: "um contrato validamente celebrado é vinculatório entre as partes. Ele somente pode ser modificado ou extinto em conformidade com o disposto em suas próprias cláusulas, ou pelo comum acordo das partes, ou ainda segundo previsão diversa contida nos presentes Princípios." 18 (grifou-se).

A doutrina internacional sustenta que o princípio no qual direitos e obrigações incidem apenas ao contrato celebrado entre as partes deriva da aplicação da doutrina do "privity of contract", reconhecido tanto nas jurisdições de civil law como naquelas de common law. ${ }^{19}$

Desta maneira, infere-se que a cláusula de arbitragem, sendo um verdadeiro contrato, independente do contrato em que estiver inserta, apenas produzirá efeitos entre as partes contratantes.

\title{
1.2 A necessidade da cláusula de arbitragem ser celebrada por escrito
}

A Lei de Arbitragem Brasileira definiu a cláusula compromissória, em seu artigo $4^{\circ}$, como a:

\begin{abstract}
"convenção através da qual as partes em um contrato comprometem-se a submeter à arbitragem os litígios que possam vir a surgir, relativamente a tal contrato.

$\S 1^{\circ}$ A cláusula compromissória deve ser estipulada por escrito, podendo estar inserta no próprio contrato ou em documento apartado que a ele se refira."
\end{abstract}

\footnotetext{
${ }^{17}$ Os princípios do Unidroit, nas palavras do atual secretário geral do Instituto para Unificação do Direito Privado (Unidroit) José Ângelo Estrella Faria, são princípios "elaborados por um grupo composto de especialistas de direito dos contratos e de representantes dos principais sistemas jurídicos do mundo, eles são o produto de uma vasta obra de direito comparado entre sistemas nacionais, inspirando-se igualmente de fontes internationnais, e aliando análise doutrinária e prática" (VILLELA, João Baptista et al. Princípios Unidroit Relativos aos Contratos Comerciais Internacionais 2004. São Paulo: Quartier Latin, 2009. p. v.).

${ }^{18}$ Ibid. p. 11

${ }^{19}$ Nesse sentido: BORN, Gary B. International Commercial Arbitration. Vol. I. Alphen aan den Rijn: Kluwer Law International, 2009. p. 1133.
} 
Em outro dispositivo (inciso II do art. 37), a Lei de Arbitragem Brasileira reforça a ideia de a cláusula ser escrita. É necessário, segundo o art. 37, II, da referida lei, a apresentação do "original da convenção de arbitragem ou cópia devidamente certificada, acompanhada de tradução oficial" para a admissibilidade de ação homologatória.

Além da Lei de Arbitragem, a matéria também é disciplinada pela Convenção de Nova Iorque de 1958, incorporada no Direito brasileiro pelo Decreto $\mathrm{n}^{\circ}$ 4.311/02, a qual estabelece no artigo II.1 que cada Estado signatário deverá reconhecer o acordo escrito:

"pelo qual as partes se comprometem a submeter à arbitragem todas as divergências que tenham surgido ou que possam vir a surgir entre si no que diz respeito a um relacionamento jurídico definido, seja ele contratual ou não, com relação a uma matéria passível de solução mediante arbitragem."

Acrescenta o segundo inciso do referido dispositivo que se deve entender por acordo escrito "uma cláusula arbitral inserida em contrato ou acordo de arbitragem, firmado pelas partes ou contido em troca de cartas ou telegramas.',

A esse respeito, cumpre trazer excerto do laudo arbitral proferido no caso Banque Arabe et Internationale d'Investissement v. Inter-Arab Investment Guarantee Corp. Confira-se, in verbis:

\begin{abstract}
"contrary to litigation in front of state courts where any interested party can join or be adjoined to protect its interests, in arbitration only those who are parties to the arbitration agreement expressed in writing could appear in the arbitral proceedings either as claimants or defendants. This basic rule, inherent to the essentially voluntary nature of arbitration, is recognised internationally by virtue of Article II of the New York Convention." ${ }^{20}$
\end{abstract}

\footnotetext{
${ }^{20}$ Arbitragem ad hoc Banque Arabe et Internationale d'Investissement v. Inter-Arab Investment Guarantee Corp. Laudo proferido em 17 de Novembro de 1994 (Apud. HANOTIAU, Bernard. Complex Arbitrations: Multiparty, Multicontract, Multi-issue and Class Actions. The Hague: Kluwer Law International, 2005. p. 7).
} 
Anote-se, ainda, que a Lei Modelo de Arbitragem da UNCITRAL, em sua opção I para a redação do art. $7^{\circ}$ (definition and form of the arbitration agreement), dispõe que a cláusula compromissória deve ser por escrito, esmiuçando o que se entende de "por escrito". Observe-se abaixo:

"The arbitration agreement shall be in writing.

An arbitration agreement is in writing if its content is recorded in any form, whether or not the arbitration agreement or contract has been concluded orally, by conduct, or by other means.

The requirement that an arbitration agreement be in writing is met by an electronic communication if the information contained therein is accessible so as to be useable for subsequent reference; "electronic communication" means any communication that the parties make by means of data messages; "data message" means information generated, sent, received or stored by electronic, magnetic, optical or similar means, including, but not limited to, electronic data interchange (EDI), electronic mail, telegram, telex or telecopy.

Furthermore, an arbitration agreement is in writing if it is contained in an exchange of statements of claim and defence in which the existence of an agreement is alleged by one party and not denied by the other.

The reference in a contract to any document containing an arbitration clause constitutes an arbitration agreement in writing, provided that the reference is such as to make that clause part of the contract."

É interessante notar que esta opção para a redação do art. $7^{\circ}$ da Lei Modelo de Arbitragem da UNCITRAL apresenta uma flexibilização do que se entende da expressão "por escrito". Como visto, a Convenção de Nova Iorque apresenta a expressão "troca de cartas e telegramas". É imperioso frisar que a referida convenção foi celebrada em 1958, tendo os meios de comunicação evoluído significativamente desde então.

A Lei Modelo da UNCITRAL abre portas, portanto, para que o acordo de vontades entre as partes possa ser formalizado por meio de e-mail com certificação eletrônica, fac-símiles e quaisquer outros meios que 
surjam e que possam permitir a documentação, por escrito, da convenção de arbitragem.

A razão de o legislador ter adotado a forma escrita como requisito da cláusula compromissória é justificada pela doutrina para permitir ao interessado o exercício de seus direitos de impor a instituição da arbitragem a parte resistente ou de afastar o juízo estatal, quando a cláusula de arbitragem restar violada. ${ }^{21}$

A doutrina majoritária, brasileira e internacional, portanto, inclina-se em reconhecer apenas a cláusula compromissória celebrada por escrito. Ressalte-se, entretanto, que vale como prova de sua existência, acordo contido em correspondências e telegramas e, naturalmente, em outros meios que permitam a verificação do acordo em documento escrito.

A necessidade de a cláusula compromissória ser formalizada por escrito já foi objeto de importantes decisões do Superior Tribunal de Justiça e, anteriormente à Emenda Constitucional $n^{\circ} 45$, do Supremo Tribunal Federal.

Na SEC n ${ }^{\circ} 866^{22}$, julgada em 17 de maio de 2006, a Corte Especial do Superior Tribunal de Justiça indeferiu o pedido de homologação de sentença estrangeira, dentre outros motivos, sob o fundamento de que a decisão homologanda ofendia a ordem pública nacional, uma vez que o reconhecimento da competência do juízo arbitral dependeria da existência de convenção de arbitragem e não havia, na hipótese em comento,

\footnotetext{
${ }^{21}$ Confira-se, nessa esteira, as lições de: MARTINS, Pedro A. Batista. Op. cit., p. 78 e BLACKABY, Nigel et al.. Op. cit., p. 89.

${ }^{22}$ STJ, SEC n. 866, Rel. Ministro Felix Fischer, Brasília, 17 mai. 2006.
} 
elementos seguros para a comprovação da cláusula compromissória pelo fato de se tratar de contratos verbais ${ }^{23}$.

O Supremo Tribunal Federal, ao julgar a SEC 6.753-7, em 2002, sob relatoria do Ministro Maurício Corrêa, já esposara entendimento no sentido de que:

\begin{abstract}
"a convenção de arbitragem é a fonte ordinária do direito processual arbitral, espécie destinada à solução privada dos conflitos de interesses e que tem por fundamento maior a autonomia de vontade das partes. Estas, espontaneamente, optam em submeter os litígios existentes ou que venham a surgir nas relações negociais à decisão de um árbitro, dispondo da jurisdição estatal comum. Tal possibilidade, aplicável aos conflitos envolvendo interesses disponíveis, traduz-se, na realidade, em exclusão da jurisdição estatal. Deve, por isso mesmo, diante de sua excepcionalidade e importância, revestirse de expressa e manifesta vontade dos contratantes, na forma do que estabelecem os artigos $4^{\circ}, 5^{\circ}$ e $6^{\circ}$ da Lei de Arbitragem." 24
\end{abstract}

Assim, em virtude das disposiçõos legais, da doutrina e das sólidas decisões jurisprudenciais, verifica-se que a convenção de arbitragem deverá necessariamente ser formalizada por escrito, ou através de correspondências e documentos (seja e-mail, fac-símile, dentre outros meios) que permitam aferir a real intenção das partes ao decidir-se pela jurisdição arbitral.

\footnotetext{
${ }^{23}$ Ressalte-se que o fundamento da ordem pública é tecnicamente questionável, pois não se trata, a rigor, de ofensa à ordem pública, mas simplesmente da falta de um requisito de validade da convenção arbitral (art. 38, II, da Lei de Arbitragem Brasileira). A esse respeito, confira-se a recente SEC no 885 (STJ, SEC n. 885, Rel. Francisco Falcão, Brasília, 02 ago. 2010). Referido acórdão não aduz sobre ordem pública ao indeferir a homologação de uma sentença arbitral estrangeira diante da inexistência de cláusula compromissória.

${ }^{24}$ STF, SEC n. 6753-7, Rel. Mauricio Corrêa, Brasília, 13 jun. 2002.
} 


\title{
1.30 requisito do consentimento das partes - um dos pilares da arbitragem $^{25}$
}

Deve-se ter em mente que a arbitragem está fundada na vontade das partes. William W. Park com maestria afirma que "like consummated romance, arbitration rests on consent ${ }^{\prime 26}$. É o consentimento que reflete a intenção das partes na adoção da arbitragem para solucionar os conflitos que possam surgir de determinada relação ou negócio jurídico. ${ }^{27}$

Fouchard, Gaillard e Goldman lecionam que "consent to an arbitration agreement lies in the parties' common intention to submit disputes which have arisen or which may arise between them to one or more private adjudicators" 28 .

A doutrina brasileira também se posiciona no mesmo sentido, sustentando que não existe arbitragem sem que haja a demonstração de que houve o consenso entre as partes para submeter a disputa ao juízo arbitral. ${ }^{29}$

Cumpre trazer à baila que a jurisprudência brasileira vem acompanhando este entendimento. Na SEC n 978 (julgada em 17 de dezembro de 2008), a Corte Especial do STJ afirmou que a ausência de:

\begin{abstract}
"inequívoca demonstração da manifestação de vontade de a parte aderir e constituir o Juízo arbitral ofende à ordem pública, porquanto afronta princípio insculpido em nosso ordenamento jurídico, que exige aceitação expressa das partes por
\end{abstract}

\footnotetext{
${ }^{25}$ Nas palavras de Bernard Hanotiau: "one should not forget that consent is the fundamental pillar of international arbitration" (HANOTIAU, Bernard. Op. cit., p. 52).

${ }^{26}$ PARK, William W. Non Signatories and International Contracts: an Arbitrators Dilemma. In: HOUT, Tjaco T. van den (Org.). Multiple Party Actions in International Arbitration. Oxford: Oxford University Press, 2008. p. 3-33.

${ }^{27}$ Nessa linha: BORN, Gary B. Op. cit., p. 1110.

${ }^{28}$ FOUCHARD, Philippe et al.. Op. cit., p. 253.

${ }^{29}$ Confira-se: PEREIRA LIMA, Flávio; MIRANDA, Daniel Calhman. Arbitragem no Brasil. A Extensão da Cláusula Compromissória a Partes não Signatárias no Direito Brasileiro. São Paulo: Impressão Régia, 2010. p. 18.
} 
submeterem a solução dos conflitos surgidos nos negócios jurídicos contratuais à arbitragem." 30

Percebe-se, portanto, que é o consenso entre as partes que autoriza os árbitros a julgar determinada disputa, em detrimento da justiça estatal. Sendo assim, é indispensável que exista, nas palavras de Flávio Pereira Lima e Daniel Calhman de Miranda:

"clara e inequívoca demonstração de que as partes manifestaram sua intenção de submeter o litígio à arbitragem, sob pena de, na ausência de tal manifestação de vontade, a sentença arbitral não ser reconhecida pela justiça estatal brasileira." 31

${ }^{30}$ STJ, SEC n. 978, Rel. Ministro Hamilton Carvalhido, Brasília, 17 dez. 2008.

${ }^{31}$ PEREIRA LIMA, Flávio; MIRANDA, Daniel Calhman. Op. cit., p. 18. 


\section{Capítulo 2 - A possibilidade de extensão dos efeitos da cláusula compromissória no Direito comparado}

Apresentada a regra geral, passa-se à exceção ${ }^{32}$ à regra, ou seja, as hipóteses em que se justifica a extensão dos efeitos da cláusula compromissória para aquelas partes que não assinaram a cláusula em questão.

Neste capítulo, analisar-se-á o tema à luz do Direito comparado. Para tanto, os seguintes argumentos serão abordados (i) a teoria do "group of companies", a qual engloba a doutrina do "alter ego", "piercing the corporate veil" ou "disregard of the legal entity" e o caso Dow Chemical; (ii) o "implied consent"; e, (iii) a teoria do "group of contracts" ou "contratos coligados".

Ressalte-se que a doutrina estrangeira enumera outros argumentos para a extensão dos efeitos da cláusula de arbitragem, tais como: (i) "representation and agency"; (ii) "third-party beneficiaries and guarantee clauses (clauses de porte-for)"; (iii) "universal and individual transfers"; (iv) "estoppel"; (v) "incorporation by reference"; (vi) "existence between the parties of a community of rights and interests"; e, (vi) "equity and good administration of Justice". 33

Todavia, para fins deste trabalho monográfico, não aborda-se os argumentos supracitados, em virtude de não apresentarem grande relevância no meio acadêmico ou por se distanciarem dos argumentos que serão

\footnotetext{
${ }^{32}$ Como bem observado por Carlos Maximiliano: "Melhor e com freqüencia maior do que a letra crua indicam se a exegese deve ser mais, ou menos, estrita os motivos, o fim colimado, a razão lógica, os valores jurídico-sociais que deram vida à regra e a justificam no sistema geral da legislação. Como sempre sucede, a propósito de quaisquer questôes de Direito, também na órbita das normas excepcionais orienta-se o hermeneuta pela perspectiva do resultado provável deste ou daquele modo de agir, atende às conseqüências decorrentes da interpretação literal, ou rigorosa do texto" (MAXIMILIANO, Carlos. Op. cit., p. 237-238).

${ }^{33}$ Nesse sentido: HANOTIAU, Bernard. Op. cit., p. v-vi.
} 
analisados no próximo capítulo, no qual se faz um estudo da possibilidade da extensão dos efeitos da cláusula compromissória à luz do Direito brasileiro.

Dito isso, antes de adentrar a análise dos argumentos, cumpre tecer alguns esclarecimentos. Em primeiro lugar, é de suma importância determinar a lei aplicável à convenção de arbitragem, como passo lógico indispensável para se discutir os efeitos e a extensão desta mesma convenção. Nesse sentido, William Park assevera:

\begin{abstract}
"Choice of law questions can present themselves to arbitrators and courts in very different procedural contexts. Arbitrators need to decide whether the factual and legal context of the dispute permits joinder of an entity that never signed the contract. Courts, however, may need to decide the preliminary matter of whether they even have jurisdiction to entertain an application with respect to foreign proceedings., ${ }^{34}$
\end{abstract}

Como se verá mais a frente no emblemático caso Dow Chemical, por exemplo, os árbitros decidiram que deviam se ater à vontade das partes para determinar os efeitos e a extensão da convenção, além dos usos do comércio internacional e também da ordem pública internacional.

Em segundo lugar, muitas vezes, para que se justifique a extensão dos efeitos da cláusula compromissória, mais de um argumento é utilizado ou, até mesmo, estes mesmos argumentos interagem e se complementam.

Nessa esteira, William Park leciona que:

\footnotetext{
"In practice, of course, arguments of joinder overlap. A single fact pattern might lend itself both to disregard of the corporate form and to finding implied consent. A parent company's fraudulent manipulation of an undercapitalized subsidiary could justify disregard of the corporate form, as well as a finding that
}

\footnotetext{
${ }^{34}$ PARK, William W. Op. cit., p. 11.
} 
the subsidiary acted merely as agent for the parent company, which was the true contracting party"35

Referido autor conclui seu raciocínio ao dizer que:

"The proverbial devil in the detail lurks in the complex fact patterns underlying most situations that might justify extension of arbitration clauses. The criteria most relevant to joinder do not yield to facile identification or application, in part because arbitrators often consider and apply overlapping theories. Often, the decision to join a non-signatory rests on more than one factor, bringing to mind the Continental expression un faisceau d'indices - 'a bundle of criteria'". 36

Assim, tendo-se em mente que é imperioso determinar a lei aplicável à cláusula de arbitragem e que um único fato pode dar causa à aplicação de mais de uma teoria (dando um conforto maior aos árbitros para decidirem acerca da questão da extensão dos efeitos da cláusula compromissória), explica-se nos próximos tópicos os argumentos, propriamente ditos, mais utilizados no Direito comparado. ${ }^{37}$

\subsection{A teoria do "Group of Companies" ${ }^{38}$ e o caso Dow Chemical}

A origem da doutrina do "group of companies" 39 remonta ao caso paradigmático Dow Chemical (ICC Case no 4131). No referido caso, quatro empresas pertencentes ao grupo Dow Chemical (a matriz americana, duas subsidiárias suíças e uma francesa) iniciaram um procedimento arbitral

\footnotetext{
${ }^{35}$ Ibid. p. 6.

${ }^{36}$ Ibid. p. 10.

${ }^{37}$ Saliente-se que esta diferença estanque entre os argumentos utilizados no Direito comparado é feita apenas para fins didáticos.

${ }^{38}$ Saliente-se que Bernard Hanotiau tece críticas ao termo "group of companies". Para o referido autor, é preferível evitar o uso da expressão "group of companies doctrine" como uma ferramenta de fundamentação para se decidir se uma cláusula arbitral poderia ser estendida para uma empresa não signatária do grupo econômico. Desta forma, ele explica que "there is a risk that the formula will be used as a shortcut permitting avoidance of rigorous legal reasoning, to quickly agree without substantial analysis, to the extension of the relevant arbitration clause to non-signatory comapanies of the group" (HANOTIAU, Bernard. Op. cit., p. 50).

${ }^{39}$ Fouchard, Gaillard e Goldman atentam que o argumento do "group of companies" "can only arise where each entity has a separate legal personality. If one of the entities is merely a branch of another entity, any arbitration agreement, the former signs will be extended to the latter simply because together both entities comprise a single juridical person" (FOUCHARD, Phillippe et al.. op. cit., p. 282-283).
} 
contra a sociedade Isover Saint-Gobain. Todavia, das quatro requerentes, apenas duas (as subsidiárias suíças) tinham assinado contratos de distribuição, com a requerida, que possuíam cláusula de arbitragem com as regras da Câmara de Comércio Internacional.

No caso, cuja sede era a França, o tribunal arbitral proferiu laudo parcial, no qual reconheceu a sua jurisdição perante as quatro empresas do grupo Dow Chemical. No aludido laudo, os árbitros definem o que seria um grupo de companhias. Confira-se, in verbis:

"group of companies, despite the distinct legal status of each of the companies, represents a single economic reality which the arbitral tribunal must take into account when ruling on its jurisdiction" 40

Gary Born conceitua "group of companies":

"where a company is part of a corporate group, is subject to the control of (or controls) a corporate affiliate that has executed a contract and is involved in the negotiation or performance of that contract, then it may in some circumstances invoke or be subjected to an arbitration clause contained in that contract, notwithstanding the fact that it has not executed the contract."

Ressalte-se, por oportuno, que a noção de "single economic reality" dada pelo laudo parcial no caso Dow Chemical não implica em dizer que sempre que uma empresa assinar uma cláusula de arbitragem, todo o grupo econômico será parte na mencionada cláusula.

A esse respeito, os professores Berthold Goldman e Michel Vasseur, árbitros que compuseram o tribunal arbitral no caso Dow Chemical, aduzem:

\footnotetext{
${ }^{40}$ Apud. MAYER, Pierre. Extension of the Arbitration Clause to Non-Signatories Under French Law. In: HOUT, Tjaco T. van den (Org.). Multiple Party Actions in International Arbitration. Oxford: Oxford University Press, 2008. p. 189-199.

${ }^{41}$ BORN, Gary B. Op. cit., p. 1167.
} 
"The 'economic reality' of the group was not in itself sufficient, but was only to be 'taken into account' in order to assess the true intention of the various companies. Indeed, the tribunal had noted in the award that all the entities of the Dow Chemical Group that were involved in the dispute considered themselves to be contractual partners of the distributors and that, similarly, the distributors considered that they had contracted with all of these entities." ${ }^{42}$

Com esse conceito fixado, vale destacar mais um excerto do laudo arbitral, no qual os árbitros concluem que a cláusula de arbitragem obriga todas as empresas do grupo Dow Chemical, as quais:

\begin{abstract}
"by virtue of their role in the conclusion, performance, or termination of the contracts containing said clauses, and in accordance with the mutual intention of all parties to the proceedings, appear to have been veritable parties to these contracts or to have been principally concerned by them and the disputes to which they may give rise" ${ }^{\text {"3 }}$
\end{abstract}

Assim, pode-se inferir que a assinatura de uma convenção de arbitragem constitui apenas um ato formal que comprova o consentimento da parte em se submeter ao procedimento arbitral. Além disso, como qualquer outra formalidade, tal ato pode ser dispensando se a finalidade para a qual ele existe (na hipótese vertente, a comprovação do consentimento) puder ser alcançada de outra maneira. Noutros termos, se existir outro modo de comprovar o consentimento, o simples ato de formalização por meio da assinatura é dispensável. Restou claro no caso Dow Chemical que interessava mais aos árbitros a realidade econômica dos contratos do que meros formalismos jurídicos. ${ }^{44}$

\footnotetext{
${ }^{42}$ MAYER, Pierre. Op. cit., p. 190.

${ }^{43}$ Apud. BORN, Gary B. Op. cit., p. 1168-1169.

44 Nessa esteira, confira-se: ALVES, Rafael Francisco. Clássicos da Arbitragem. Corte Internacional de Arbitragem da CCI - Sentença Parcial $n^{\circ} 4.131$, de 23 de setembro de 1982 Dow Chemical v. Isover Saint Gobain. Revista Brasileira de Arbitragem. São Paulo, n. 20, out./dez.2008.
} 
Frise-se, ainda, que o laudo parcial foi posteriormente submetido à Corte de Apelação de Paris, a qual rejeitou o pedido de anulação da Isover Saint-Gobain por dois motivos.

$\mathrm{O}$ primeiro se refere ao fato de que o tribunal se pautou pelo consentimento tácito ${ }^{45}$, entendendo que todas as partes acordaram que as empresas não signatárias deveriam estar vinculadas às cláusulas compromissórias. O segundo se refere ao fato de que a requerida não contestou em nenhum momento a noção de "group of companies", como norma costumeira de comércio internacional.

Por fim, cumpre trazer à baila um outro importante aspecto do caso Dow Chemical. No caso, o tribunal arbitral pôde decidir acerca da extensão dos efeitos da cláusula e utilizar o argumento do grupo de companhias, em virtude da lei aplicável à convenção de arbitragem.

Nesse diapasão, recorre-se às palavras de Rafael Francisco Alves, o qual ao comentar o caso aduz:

\begin{abstract}
"Sendo a convenção silente quanto à lei aplicável a ela própria, o Tribunal decidiu que não estaria vinculado a qualquer direito nacional (tampouco o direito francês), devendo se ater apenas à vontade das partes para determinar o escopo, os efeitos e a extensão da convenção, além dos usos do comércio internacional. Dessa forma, a análise do Tribunal Arbitral a respeito de sua própria competência deveria passar pelo crivo apenas da vontade das partes e, em última instância, da ordem pública internacional, sem estar vinculado a qualquer direito internacional, seguindo-se, assim, a conhecida teoria autonomista ou universalista da arbitragem" ${ }^{, 46}$
\end{abstract}

Diante do exposto, percebe-se a razão pela qual o "leading case" Dow Chemical se tornou tão célebre. Em primeiro lugar, introduziu no

\footnotetext{
${ }^{45}$ Como dissemos na introdução a este capítulo, muitas vezes para apenas um fato há mais de um argumento possível que possa fundamentar a extensão dos efeitos da cláusula compromissória. O consentimento tácito é um outro argumento que analisaremos mais à frente.

${ }^{46}$ Ibid. p. 196-197.
} 
mundo da arbitragem internacional a definição de "group of companies", conceito por meio do qual se inferiu, através da formação de uma só realidade econômica, que a simples falta de assinatura não obsta necessariamente a extensão dos efeitos da cláusula compromissória à partes não signatárias.

Em segundo lugar, o referido caso demonstrou a importância da lei aplicável à disputa. Se não estiver expressa na convenção de arbitragem, qualquer menção a um diploma legal aplicável, o tribunal arbitral poderá invocar o princípio da autonomia da cláusula arbitral e concluir por sua desvinculação a qualquer direito nacional, devendo se ater à vontade das partes para determinar o escopo, os efeitos e a extensão da convenção de arbitragem, além dos usos e práticas do comércio internacional, como ocorreu no caso Dow Chemical.

\subsubsection{A doutrina do "Alter Ego", "Piercing the Corporate Veil" ou Disregard of the legal entity"}

Como se viu no primeiro capítulo, a cláusula compromissória apenas obriga as empresas que concordaram em levar a disputa para a arbitragem. Outros membros do grupo econômico (holding, subsidiárias e acionistas/quotistas) não perderiam, nas palavras de William Park, um "day in court simply because an arbitration clause has been signed by one entity within a corporate group". ${ }^{47}$

Isso se dá, via de regra, em virtude de um princípio de direito comercial reconhecido no mundo todo, qual seja, o da limitação de

\footnotetext{
${ }^{47}$ PARK, William W. Op. cit., p. 18.
} 
responsabilidade das sociedades ${ }^{48}$. Nas palavras do professor de Berkeley, Melvin Aron Eisenberg:

"under modern statutes, a shareholder's risk is ordinarily limited to her investment - that is, the most a shareholder stands to lose, even if the corporation fails, is the amount that she paid for her shares" ${ }^{, 49}$

Paul. D. Davies, professor da London School of Economics, leciona a razão subjacente ao princípio da limitação de responsabilidade. Segundo ele:

\begin{abstract}
"the company laws of all economically advanced countries make available corporate vehicles through which business can be carried on with the benefit of limited liability for their members. (...) For most shareholders this means that, once the shares have been paid for, whether they were acquired directly from the company or from an existing shareholder, the worst fate that can befall them if the company becomes insolvent is that they lose the entire value of their investment"
\end{abstract}

John Armour, Henry Hansmann e Reinier Kraakman complementam o raciocínio apresentado pelo professor Paul D. Davies ao pontuarem que: "this evolution [rule of limited liability that has been associated with the corporate form] indicates strongly the value of limited liability as a contracting tool and financing device"

Nessa linha, a Suprema Corte Americana, no caso Anderson v. Abbott, enunciou a seguinte máxima: "[1]imited liability is the rule, not the

\footnotetext{
${ }^{48}$ John Armour, Henry Hansmann e Reinier Kraakman, professores de Oxford, Yale e Harvard, respectivamente, aduzem que "today limited liability has become a nearly universal feature of the corporate form." (KRAAKMAN, Reinier et al.. The Anatomy of Corporate Law - A Comparative and Functional Approach. Second Edition. Oxford: Oxford University Press, 2009. p. 9).

${ }^{49}$ EISENBERG, Melvin Aron. Corporations and Other Business Organizations: Cases and Materials. Ninth Edition. New York: Foundation Press, 2005. p. 220.

${ }^{50}$ DAVIES, Paul L. Gower and Davies' Principles of Modern Company Law. Eighth Edition. London: Sweet \& Maxwell Ltd, 2008. p. 193.

${ }^{51}$ KRAAKMAN, Reinier et al.. Op. cit., p. 10.
} 
exception; and on that assumption large undertakings are rested, vast enterprises are launched, and huge sums of capital attracted",52.

Frise-se, todavia, que o princípio da limitação de responsabilidade resguarda não somente acionistas/quotistas, como também outras empresas do grupo econômico.

A doutrina estrangeira aponta que um importante aspecto da divisão do patrimônio das empresas de um mesmo grupo é a possibilidade de se obter diferentes linhas de crédito. Assim, por possuírem patrimônios independentes, cada empresa do grupo pode, da maneira que melhor the convir, dar algum bem de seu patrimônio em garantia para determinado credor, de um negócio individualmente considerado. ${ }^{53}$

Em outros termos, as sociedades, geralmente, possuem suas responsabilidades limitadas, não podendo, portanto, serem responsabilizadas em montante superior ao que foi investido para "abrir" a respectiva sociedade ou terem suas responsabilidades estendidas a outras empresas do grupo econômico ao qual pertencem.

Todavia, o princípio da limitação da responsabilidade não é absoluto. A grande maioria dos ordenamentos jurídicos comporta exceções ao referido princípio. O Brasil, como se verá no próximo capítulo, adota o instituto da desconsideração da personalidade jurídica.

Nos países de "common law", tal exceção é conhecida como "alter ego", "piercing the corporate veil" ou "disregard of legal entity". Sobre a diferença na terminologia empregada, a doutrina aduz que os Estados

\footnotetext{
${ }^{52}$ TYLER, Timothy et al.. Beyond Consent: Applying Alter Ego and Arbitration Doctrines to Bind Sovereign Parents. In: HOUT, Tjaco T. van den (Org.). Multiple Party Actions in International Arbitration. Oxford: Oxford University Press, 2008. p. 155.

${ }^{53}$ A esse respeito confira-se: KRAAKMAN, Reinier et al.. Op. cit., p. 10.
} 
aplicam conceitos análogos, a despeito da variação dos rótulos e da nomenclatura utilizada. Advogados anglo-saxões falam em "piercing" ou "lifting" o véu entre acionista e sociedade. Os autores franceses costumam se referir a "abuse de droit", enquanto os alemães invocam noções de "Durchgriff" ou "seizing through". ${ }^{54}$

Tendo-se em mente o princípio da limitação da responsabilidade das sociedades, utilizar-se-á, daqui em diante, os conceitos de "alter ego" e "piercing the corporate veil", definindo-os e explicando como poderiam ser usados para trazer partes não signatárias à arbitragem.

Bernard Hanotiau traz uma distinção esclarecedora sobre os conceitos. Confira-se abaixo:

\begin{abstract}
"Under the alter ego doctrine, a corporation may be bound by an agreement entered into by its subsidiary regardless of the agreement's structure or the subsidiary's attempts to bind itself alone to its terms, where their conduct demonstrates a virtual abandonment of separateness; or corporate officers may be brought into arbitration if there exists a unity of ownership and interest between the corporate entity and the individual such that distinct personalities of corporation and individual no longer exist and to adhere to separateness would promote fraud or injustice. On the other hand, the corporate veil may be pierced to hold an alter ego liable for the commitments of its instrumentality only if: 1) the owner exercised complete control over the corporation with respect to the transaction at issue, and 2) such control was used to commit a fraud or wrong that injured the party seeking to pierce the veill,55
\end{abstract}

A Suprema Corte da Califórnia, no caso Minton v. Cavaney, também comenta acerca das expressões "alter ego" e "disregard of the corporate entity", sustentando que:

"the figurative terminology 'alter ego' and 'disregard of the corporate entity' is generally used to refer to the various situations that are an abuse of the corporate privilege.... The

\footnotetext{
${ }^{54}$ Nesse sentido: PARK, William W. Op. cit., p. 18.

${ }^{55}$ HANOTIAU, Bernard. Op. cit., p. 47.
} 
equitable owners of a corporation, for example, are personally liable when they treat the assets of the corporation as their own and add or withdraw capital from the corporation at will ...; when they hold themselves out as being personally liable for the debts of the corporation...; or when they provide inadequate capitalization and actively participate in the conduct of corporate affairs" ${ }^{\prime 56}$

A Corte Internacional de Justiça explicou a doutrina supra no caso

Barcelona Traction, de forma elucidativa, senão vejamos:

\begin{abstract}
"the process of 'lifting the corporate veil' or 'disregarding the legal entity' has been found justified and equitable in certain circumstances or for certain purposes. The wealth of practice already accumulated on the subject in municipal law indicates that the veil is lifted, for instance, to prevent misuse of the privileges of legal personality, as in certain cases of fraud or malfeasance, to protect third persons such as creditor or purchaser, or to prevent the evasion of legal requirements or of obligations" ${ }^{\text {"57 }}$
\end{abstract}

De toda forma, cumpre salientar que as jurisdições que permitem o "piercing the corporate veil", apenas "levantam o véu" da sociedade em circunstâncias extremas, quais sejam, para assegurar que acionistas controladores ou holdings de grupos econômicos sejam pessoalmente responsáveis perante os débitos da sociedade. Sendo exceção que é, os tribunais nacionais e arbitrais não costumam utilizar o "piercing the corporate veil" com muita freqüência.

Segundo os advogados Timothy Tyler, Lee Kovarsky and Rebecca Stewart:

\begin{abstract}
"whatever the theory, there appears a constant tension in the law of veil-piercing in the corporate arena between, on the one hand, wanting to encourage limited liability for the sake of investment and economic growth, and on the other, justifying the shifting of risk from shareholders to creditors that liability permits"
\end{abstract}

\footnotetext{
${ }^{56}$ EISENBERG, Melvin Aron. Op. cit., p. 240.

${ }^{57}$ Corte Internacional de Justiça, Presid. M. Bustamante y Rivero, Haia, fev. 1970. Disponível em http://www.icj-cij.org/docket/files/50/5387.pdf. Acesso em 01 nov. 2010.

${ }^{58}$ TYLER, Timothy et al.. Op.cit., p. 154.
} 
À guisa de ilustração, observe-se os requisitos utilizados por alguns ordenamentos jurídicos para "levantar o véu" das sociedades. Nos Estados Unidos, ficaram famosos os requisitos apresentados no estudo desenvolvido por Frederick J. Powell. O referido estudo possui três elementos necessários para o "piercing the corporate veil". Confira-se abaixo:

\begin{abstract}
“The first element, the 'alter ego' or 'mere instrumentality' test, requires that the subsidiary be completely under the control and domination of the parent. The second element, the 'fraud or wrong' or 'injustice' test, requires that the conduct of the defendant parent in using the subsidiary must have been somehow wrongful, fraudulent, or unjust towards the plaintff. The third element, the 'unjust loss or injury' test, or what Powell referred to as the 'proximate cause' test, requires that the plaintiff has suffered actual harm as a result of the defendant parent's conduct" 59
\end{abstract}

O Japão e muitos países da União Européia aplicam o "veil piercing" de maneira similar. Na França, e.g., procedimentos de falência podem ser estendidos a acionistas que foram negligentes acerca da integridade de suas companhias (a chamada "action en confusion de patrimoine)" 60.

$\mathrm{Na}$ Inglaterra, segundo Gary Born:

\begin{abstract}
"an alter ego relationship may be found where the corporate structure is used to evade mandatory legal obligations or the enforcement of existing and legitimate third parties rights. In a recent decision, an English court declared: 'English law insists on recognition of the distinct legal personality of companies unless the relevant contract or legislation requires or permits a broad interpretation to be given to references to members of a group of companies or the legal personality is a mere façade or sham or unlawful device",61
\end{abstract}

Já na Alemanha, o "piercing the corporate veil" não é tão comum em relação ao "group of companies", diferentemente do que ocorre em relação a acionistas controladores (que são indivíduos). Nas palavras dos

\footnotetext{
${ }^{59}$ Ibid. p. 152.

${ }^{60}$ KRAAKMAN, Reinier et al.. Op. cit., p. 139.

${ }^{61}$ BORN, Gary B. op. cit., p. 1155.
} 
professores John Armour, Gerard Hertig e Hideki Kanda, das universidades de Oxford, Zurique e Tóquio, respectivamente:

\begin{abstract}
"A supplementary set of creditor protection standards covers groups of companies in some jurisdictions, constituting a special law of corporate groups. The German Konzernrecht provides the most elaborate example of such a law, attempting to balance the interests of groups as a whole with those of the creditors and minority shareholders of their individual members. In groups based upon a contract of domination, the parent must indemnify its subsidiaries for any losses that stem from acting in the group's interests. Should this fail to happen, creditors of the subsidiary may attach its indemnification claim or sue the parent's directors for damages. More generally, even if a parent company has not entered into a contract of domination (a de facto group), it must compensate any subsidiaries that it causes to act contrary to the subsidiary's own interests. Should the parent fail to do so, creditors may sue the parent for damages" 62
\end{abstract}

Feito o esclarecimento dos conceitos relativos à doutrina do "piercing the corporate veil" e após traçar um panorama entre jurisdições distintas, é imperioso definir como ocorre a extensão dos efeitos da cláusula compromissória, por meio da teoria tratada neste tópico.

De acordo com a doutrina, na maioria dos ordenamentos jurídicos mais desenvolvidos, demonstrar uma relação de "alter ego", em convenções de arbitragem, requer fortes evidências de que uma empresa dominava as ações rotineiras de outra e/ou exercia este poder para fraudar ou cometer injustiças contra um terceiro. ${ }^{63}$

Como se verá adiante, a jurisprudência, a despeito de ser vacilante, já estendeu os efeitos da cláusula de arbitragem para partes não signatárias, com base na teoria do "piercing the corporate veil".

O doutrinador John Townsend aduz que:

\footnotetext{
${ }^{62}$ KRAAKMAN, Reinier et al.. Op. cit., p. 140.

${ }^{63}$ Confira-se, nesse diapasão, a lição de: BORN, Gary B. Op. cit., p. 1154.
} 


\begin{abstract}
"several courts have discussed the possibility of piercing the corporate veil or using alter ego theory to bind nonsignatory parties to, or to give them the benefit of, arbitration clauses in contracts entered into by their affiliates. When the courts have done so, the claims against the nonsignatory and its affiliate have been closely related. For instance, the 4th Circuit said:

'When the charges against a parent company are based on the same facts and are inherently inseparable, a court may refer claims against the parent to arbitration even though the parent is not formally a party to the arbitration agreement... If the parent corporation was forced to try the case, the arbitration proceedings would be rendered meaningless and the federal policy in favor of arbitration effectively thwarted" ${ }^{\prime 64}$.
\end{abstract}

No caso Carte Blanche (Singapore) Pte, Ltd. v. Diners Club

International, Inc, a CBS, uma franqueada, propôs uma ação para obrigar a

Diners Club, a holding do seu franqueador, CBI, a cumprir um laudo arbitral, o qual reconheceu o inadimplemento do contrato de franquia por parte da Diners Club. O Tribunal do "Second Circuit" entendeu que:

\begin{abstract}
"[E]xceptions are made [to the presumption of corporate separateness] in two broad situations: to prevent fraud or other wrong, or where a parent dominates and controls a subsidiary...Liability therefore may be predicated either upon a showing of fraud or upon complete control by the dominating corporation that leads to a wrong against third parties. New York law allows the corporate veil to be pierced either when there is fraud or when the corporation has been used as an alter ego... Because New York courts disregard the corporate form reluctantly, they do so only when the form has been used to achieve fraud, or when the corporation has been so dominated by an individual or another corporation... and its separate identity so disregarded, that it primarily transacted the dominator's business rather than its own and can be called the other's alter ego" 65
\end{abstract}

Em laudo proferido por tribunal arbitral ad hoc suíço, os árbitros decidiram pelo "levantamento do véu" e pela extensão à holding dos efeitos da cláusula de arbitragem celebrada por sua subsidiária. Segundo Bernard Hanotiau:

\footnotetext{
${ }^{64}$ TOWNSEND, John M. Agency, Alter Ego and Other Identity Issues: Nonsignatories and Arbitration. ADR - The Newsletter of Dispute Resolution Law and Practice. New York City, v. 3, $\mathrm{n}^{\circ}$ 3, set.1998.

${ }^{65}$ TYLER, Timothy et al.. Op. cit. p. 162.
} 


\begin{abstract}
"the arbitral tribunal based its decision on the total control and dominance of the subsidiary by the parent company, the inadequacy of the subsidiary's capital in view of the nature and value of the transactions it entered, the total confusion in their administation, management and assets, and the fact that the subsidiary was not correctly dissolved and its assets channeled to the parent company" 66
\end{abstract}

Diante da jurisprudência citada e lembrando o que foi dito antes de esmiuçar os argumentos em favor da extensão da cláusula compromissória, repita-se que muitas vezes um só argumento não é capaz de fundamentar a referida extensão. ${ }^{67}$

Para finalizar este tópico, vale a pena citar as palavras de Frank $\mathrm{H}$. Easterbrook e Daniel R. Fischel: “piercing' seems to happen freakishly. Like lightning, it is rare, severe, and unprincipled." 68

Assim, apesar de ser possível, por meio da doutrina do "alter ego", a extensão dos efeitos da cláusula de arbitragem para partes não signatárias, tal possibilidade dependerá muito da análise do caso concreto. Ou seja, da lei aplicável ao caso, do sítio da arbitragem, e, principalmente, se há indícios suficientemente fortes que levem a crer que o acionista/quotista ou a holding do grupo econômico possam ser responsabilizados no lugar da sociedade signatária da cláusula compromissória.

\title{
2.20 "implied consent"
}

O "implied consent" é definido pela doutrina como "consent inferred from one's conduct rather than from one's direct expression". ${ }^{69} \mathrm{Na}$

\footnotetext{
${ }^{66}$ HANOTIAU, Bernard. Op. cit., p. 58.

${ }^{67}$ Cite-se nesse sentido a lição de John Townsend: "it is important to note that a corporate relationship alone is not sufficient to bind a nonsignatory to an arbitration agreement. (...) The 10th Circuit said: 'Courts do not lightly pierce the corporate veil in deference to the strong policy favoring arbitration"” (TOWNSEND, John M .Op. cit., p. 6-7).

${ }^{68}$ EASTERBROOK, Frank H; FISCHEL, Daniel R. Corporate Practice Commentator. Limited Liability Corporation. University of Chicago Law Review. Chicago, n. 52, p. 89, 1985.

${ }^{69}$ GARNER, Bryan A. (editor in chief). Black's Law Dictionary. Eighth Edition. Dallas: Thomson West, 2004. p. 323.
} 
realidade, ele figura por trás de todos os argumentos que fundamentam a extensão dos efeitos da cláusula de arbitragem para partes não signatárias. Sendo assim, percebe-se, de plano, a importância do instituto para este trabalho monográfico.

Como exemplo do que foi dito acima, os fatos que podem ser explicados pela teoria do "group of companies", a qual, como se viu, envolve a participação de outra empresa do grupo econômico na negociação e na execução do contrato, podem também servir de fundamento para o “implied consent”. A esse respeito, confira-se excerto de decisão da Corte de Apelação de Paris:

\footnotetext{
"in international arbitration law, the effects of the arbitration clause extend to parties directly involved in the performance of the contract, provided that their respective situations and activities raise the presumption that they were aware of the existence and scope of the arbitration clause, so that the arbitrator can consider all economic and legal aspects of the dispute". ${ }^{70}$
}

Pode-se inferir da decisão acima que o envolvimento das partes na negociação e execução do contrato não só poderia ser explicada pela teoria do "group of companies", como também pelo "implied consent". Como se verá a seguir, criou-se a presunção de que as partes tinham ciência da existência e da finalidade da cláusula se arbitragem, admitindo que tivessem consentindo em arbitrar suas disputas.

Dito isso, cumpre agora se aprofundar sobre a teoria do "implied consent". A doutrina aduz que, mesmo sem uma assinatura, a parte pode estar obrigada por uma cláusula de arbitragem, caso sua conduta indique que ela tenha assumido a obrigação de arbitrar. ${ }^{71}$

\footnotetext{
${ }^{70}$ Apud. FOUCHARD, Philippe et al.. Op. cit., p. 282.

${ }^{71}$ Nesse sentido: TOWNSEND, John M. Op. cit., p. 3. e BORN, Gary B. Op. cit., p. 1150.
} 
Gary Born delimita a principal questão no que tange o "implied consent". Confira-se abaixo:

\begin{abstract}
"The fundamental question in the context of implied consent is whether the parties' objective intention was that a particular entity be a party to the arbitration clause. Although the nonsignatory's intent is often most controversial, the intention of other parties to be bound by the agreement to arbitrate with the non-signatory is also necessary. That is, even if a non-signatory intended to be bound by the arbitration agreement, one must also determine whether the signatory (and other) parties to the agreement accepted it as such: for commercial or other reasons, signatories to an arbitration agreement may wish to extend their obligations to arbitrate only to those entities that have signed the agreement, and not to others." 72
\end{abstract}

Percebe-se, pelo exposto, que o consentimento não deve ser somente de algumas partes ou daquelas que não assinaram a cláusula compromissória, mas sim, de todas as partes envolvidas, inclusive, das signatárias.

\title{
Além disso, a doutrina é enfática ao afirmar que as questões de “implied consent" surgem em numerosas situações ${ }^{73}$. Por essa razão, o advogado Blaise Stucki pondera que:
}

"It is hardly possible to make a list of situations in which a third party will be deemed to have tacitly consented to an arbitration agreement, i.e. the situations in which consent may be inferred from its conduct. Obviously, a third party suing on the basis of an arbitration agreement will be deemed to have consented to it. On the other hand, one can reasonably consider that, under most national laws, including Swiss law, the active and substantial participation of a third party in the negotiation or performance of a contract containing an arbitration aagreement is not, in and of itself, sufficient for the third party to be deemed bound by the arbitration agreement. There must be certain specific circumstances from which the third party's consent to the arbitration agreement may be inferred. By way of example, one may think of a party, co-defendant in court proceedings, which, together with its co-defendant, relies on the arbitration agreement entered into by the latter the plaintiff to challenge the jurisdiction of the court. If the plaintiff then initiates arbitration

\footnotetext{
${ }^{72}$ Ibid. p. 1150-1151.

${ }^{73}$ Observe-se: Ibid. p. 1151.
} 
proceedings against the two co-defendants, the one that is not a party to the arbitration agreement will be barred from raising this objection to challenge the jurisdiction of the arbitral tribunal" 74

\section{O exemplo citado por Blaise Stucki também é comentado por} Bernard Hanotiau $^{75}$ como evidência de consentimento implícito. Confira-se abaixo:

"If there is no evidence of an express agreement, courts and arbitral tribunals will often take into consideration the conduct of the party concerned as an expression of implied consent or, as we will see later, as a substitute for consent. For example, if $\mathrm{A}$ and $\mathrm{B}$ enter into an agreement containing an arbitration clause and subsequently A sues B in court together with $\mathrm{C}$, a non-signatory, but the latter, like $\mathrm{B}$, invokes the existence of the arbitration clause to challenge the jurisdiction of the court, an arbitral tribunal, to which the case is subsequently reffered, will be justified in considering that it has jurisdiction over $\mathrm{C}$, inferring C's consent to arbitration from the fact that it invoked the arbitration agreement in the court proceedings" ${ }^{, 76}$

A jurisprudência admite o "implied consent", mas, os elementos do caso concreto é que permitirão antever a extensão dos efeitos da cláusula de arbitragem ou não. Para uma melhor compreensão de tal posição jurisprudencial, cumpre trazer à baila casos conflitantes sobre a matéria. Confira-se, abaixo, comentários de Bernard Hanotiau sobre uma decisão da Câmara de Comércio Internacional, in verbis:

"in ICC case no. 6769 of 1991, a contract had been concluded between an African company X and a company Y from Eastern Europe. The contract, which contained an arbitration clause, provided that the materials would be equipped with a part manufactured by Z. Z had initialled the parts of annex 1 to the contract describing the characteristics of the element to be supplied. $X$ alleged the existence of defects in the item manufactured by $\mathrm{Z}$ and started arbitration proceedings against $\mathrm{Z}$ on the basis of the arbitration clause included in the contract

\footnotetext{
${ }^{74}$ STUCKI, Blaise. Extension of Arbitration Agreements to Non-Signatories. ASA Below $40-$ Conference of September 29, 2006. Geneva, p. 4.

${ }^{75}$ Como veremos no próximo capítulo, o Superior Tribunal de Justiça, na SEC no 856 , sob relatoria do Min. Carlos Alberto Direito, já utilizou este raciocínio para homologar laudo estrangeiro.

${ }^{76}$ HANOTIAU, Bernard. Op. cit., p. 36.
} 
concluded with Y. The arbitral tribunal decided that, in the absence of reciprocal undertakings, the signature of a third party, Z, did not have the effect of making this third party a party to the agreement between $\mathrm{X}$ and $\mathrm{Y}$. In this respect, the arbitrators pointed out that under the agreement, $\mathrm{X}$ assumed full responsibility for the conformity of the supplies with the agreement and that if payment for the specific item manufactured by $\mathrm{Z}$ was to be made directly by $\mathrm{X}$ to $\mathrm{Z}, \mathrm{Y}$ again took full responsibility since the payment could be made only upon its instructions. There was therefore no personal undertaking by $\mathrm{Z}$ to $\mathrm{X}$. By initialling the pages relating to the technical characteristics of the item to be manufactured, $\mathrm{Z}$ only wanted to confirm to $\mathrm{X}$ and $\mathrm{Y}$ that it was well aware of the technical elements of the Project. The arbitral tribunal further pointed out that $\mathrm{Z}$ had not played a specific role in the conclusion or the performance of the agreement." ${ }^{, 77}$

Em contrapartida, o referido doutrinador comenta uma outra decisão do ICC que acatou o "implied consent" para trazer uma parte não signatária ao procedimento arbitral. Observe-se abaixo, in verbis:

"in ICC case no. 9771 of 2001, a commodities trading company, claimant in the proceedings, negotiated a contract with shipping company $\mathrm{A}$, the second defendant in the arbitration, for the supply of 3000 tons of a raw material. The commodities trading company faxed the contract bearing its signature to the Moscow Office of shipping company A, which signed the contract and faxed it back to the commodities trading company. The following day, the same document bearing the same contract number and date was faxed again to the commodities trading company, but with the signature of shipping company $\mathrm{B}$, the first defendant in the arbitration. The contents of the contract were unchanged except that shipping company's A name and address had been substituted by that of shipping company D. In addition, a change had been made in the article of the contract regulating the consequences of exceeding one of the quality specifications. The signature on behalf of the shipping company on both documents was the same. The commodities trading company only signed the version of the contract faxed to it by shipping company A. The contract cointained an arbitration clause providing for ICC arbitration in Stockholm. It finally appeared that the goods supplied did not meet the specifications. They were therefore rejected by the commodities trading company by a telefax to shipping company D. The claimant claimed breach of contract and reimbursement of the advance payment made to $\mathrm{D}$, as well as compensation for all other costs and damages. Since no amicable settlement could be reached, the commodities trading company instituted arbitration against both shipping companies

\footnotetext{
${ }^{77}$ Ibid. p. 33.
} 
and a sole arbitrator was appointed. First and second defendants argued that only shipping company $\mathrm{D}$, which had performed the obligations of the the seller under the contract, should be a party to the contract. The sole arbitrator found that there was no indication of an express assignment of the contract, as argued by defendants. On the other hand, although the commodities trading company accepted shipping company D also as a contractual party, this did not mean that it released shipping company A from its obligations. The contract had been signed by shipping company $\mathrm{D}$ and confirmed by shipping company A. They were therefore both bouund by the arbitration clause in the contract. "78

Por fim, vale citar dois princípios gerais de interpretação que se aplicam às clausulas de arbitragem, os quais podem ajudar a entender e aplicar a teoria do "implied consent," ao se analisar a hipótese de extensão dos efeitos da cláusula arbitral. São eles: (i) princípio da boa fé (principle of interpretation in good faith) e o (ii) princípio do contra proferentem.

O princípio de interpretação de boa fé, segundo Gustavo Tepedino:

\begin{abstract}
"impõe um padrão de conduta a ambos os contratantes, no sentido de recíproca cooperação, com consideração aos interesses comuns, em vista de se alcançar o efeito prático que justifica a própria existência do contrato" 79 .
\end{abstract}

Saliente-se, por oportuno, que o princípio 1.7 do Unidroit dispõe acerca da boa-fé. Referido princípio aduz, em sua primeira parte, que "cada uma das partes deve comportar-se segundo os ditames da boa-fé no comércio internacional" ${ }^{, 80} \mathrm{e}$, em sua segunda parte, que "as partes não podem exluir essa obrigação, ou limitar-lhe o alcance ${ }^{, 81}$. Esta segunda parte torna claro o dever das partes de comportar-se segundo os ditames da boa-fé, já que elas não podem contratualmente excluí-lo ou limitá-lo.

\footnotetext{
${ }^{78}$ Ibid. p. 33-34.

${ }^{79}$ TEPEDINO, Gustavo et al.. Op. cit. p. 16.

${ }^{80}$ VILLELA, João Baptista et al. Op. cit., p. 18.

${ }^{81}$ Ibid. p. 18.
} 
Em relação ao princípio do contra proferentem, Fouchard, Gaillard e Goldman lecionam que "is the principle that the agreement should be interpreted contra proferentem, or against the party that drafted the clause in dispute." 82

Assim como no princípio da boa-fé, também há um princípio do Unidroit acerca da regra do contra proferentem. O princípio 4.6 do Unidroit dispõe que "termos contratuais obscuros serão interpretados preferencialmente em desfavor da parte que os tenha proposto." $\$ 3$

Desta maneira, uma parte pode ser responsabilizada pela elaboração de uma cláusula contratual específica, seja porque a minutou ou porque a sugeriu. Esta parte deverá suportar, portanto, o risco de uma possível falta de clareza da formulação escolhida. ${ }^{84}$

Assim, a despeito da importância do argumento do "implied consent", já que, como se viu, pode explicar fatos que também são defensáveis por outras teorias, sua aplicação deve ser cautelosa. Saber a real intenção das partes ao estipular a cláusula de arbitragem não é das tarefas mais simples, devendo-se, portanto, levar em consideração todas as nuances do caso concreto.

\subsection{A teoria do "Group of Contracts" ou "contratos coligados"}

Outro argumento apto a ensejar a extensão dos efeitos da cláusula de arbitragem para partes não signatárias é a teoria do "group of contracts". Segundo esta teoria, nas palavras de Ricardo Lorenzetti:

"Muchos autores han tratado el tema de los contratos coligados señalando que hay "uma pluralidad coordinada de contratos,

\footnotetext{
${ }^{82}$ FOUCHARD, Philippe et al.. Op. cit., p. 259.

${ }^{83}$ VILLELA, João Baptista et al.. Op. cit., p. 131

${ }^{84}$ Confira-se Ibid. p. 131.
} 
cada uno de los cuales responde a uma causa autônoma, aun cuando em conjunto tiendan a la realización de uma operación econômica unitária y compleja'. Hay um negocio único que se desmembra em distintos contratos (...). Esta conexión entre los contratos puede darse unilateralmente (contrato accesorio de um principal), recíprocamente (contratos dependientes entre si por uma operación econômica). Siguiendo com la tesis de Galgano, se indica que la relevância principal de este instituto es que, si bien contratos mantienen su individualidad, los efectos de uno (invalidez, resolución) pueden repercutir sobre el outro" 85

A doutrina faz uma importante distinção entre os contratos que possuem uma ligação daqueles que não possuem. Afirma-se que os contratos estão ligados uns aos outros quando estão unidos em uma relação de dependência econômica ou funcional. Sendo assim, podem ser diferenciados em duas categorias. A primeira inclui grupos de contratos que coexistem para alcaçar um único objetivo: um contrato principal e contratos acessórios, por exemplo. ${ }^{86}$

A segunda categoria contempla contratos que estão unidos em uma relação de substituição ou, em outras palavras, grupos de contratos que consistem em acordos sucessivos entre as mesmas partes, nos quais o segundo se relaciona com o primeiro para aditá-lo ou resilí-lo. Como exemplo, poder-se-ia citar um contrato original e um termo de acordo, ou uma novação. Assim, contratos que não se encaixam em alguma das duas categorias não estariam coligados. ${ }^{87}$

Diante desta distinção em duas categorias, é imperioso apresentar as características inerentes à primeira, já que essa lida com a problemática de incluir partes não signatárias à arbitragem. Em relação à esta categoria (contratos com a mesma finalidade) deve-se traçar, segundo Fouchard, Gaillard e Goldman, situações diferentes:

\footnotetext{
${ }^{85}$ LORENZETTI, Ricardo. Redes contractuales: conceptualización jurídica, relaciones internas de colaboración, efectos frente a terceros. Revista de Direito do Consumidor. São Paulo, n. 8, out./dez. 1998.

${ }^{86}$ Nesse sentido: HANOTIAU, Bernard. Op. cit., p. 102-103.

${ }^{87}$ Ibid. p. 102-103.
} 
"The first is where only the heads of agreement, or framework agreement, contains an arbitration clause to which the other related contracts refer. This case presents no difficulty. The parties' intention is clear: they sought to refer all disputes arising out of the whole set of contracts to arbitration, before a single arbitral tribunal constituted in accordance with the heads of agreement.

The second case is where each of the contracts with the same objective contains its own arbitration clause (...). Once a dispute has arisen, and in the absence of an agreement between the parties on the point, the answer depends on the interpretation of the parties's intention at the outset. However, it is generally legitimate to presume that by including identical arbitration clauses in the various related contracts, the parties intended to submit the entire operation to a single arbitral tribunal. In ICC Arbitration, this situation is addressed by Article 4 (6) of the 1998 Rules, which enables the International Court of Arbitration to consolidate arbitrations between the same parties which are in connection with the same "legal relationship"." 88

A despeito dos aludidos autores entenderem que não há dificuldade no primeiro caso (contratos com a mesma cláusula de arbitragem ou com cláusulas compatíveis), a jurisprudência é dividida.

Como exemplo de laudo arbitral que refutou a consolidação de procedimentos arbitrais que se reportavam à cláusulas semelhantes de arbitragem, podemos citar o ICC case $\mathrm{N}^{\circ} 7453$, de 1994. No caso vertente:

\begin{abstract}
"There was only one contract (between A and B) but also an arbitration agreement by implied consent (between B and C). A, the claimant, was the exclusive sales agent in the United States and Canada for first defendant's (B, a German company) products. The contract contained an arbitration clause providing for ICC arbitration. After termination of the agreement by first defendant, the claimant instituted court proceedings in a United States District Court against B and one of its managing directors, $\mathrm{C}$, the second defendant. The first and second defendants invoked the arbitration clause in the contract and the District Court stayed the proceedings in favour of arbitration. Subsequently, during the arbitration, the second defendant contested the arbitral tribunal's jurisdiction over him, as he was not a party to the arbitration agreement. The claimant objected, citing the second defendant's consent to arbitration from the fact that he had invoked the arbitration agreement in the court proceedings. The arbitral tribunal considered that even if it could be so interpreted, the second defendant could not have
\end{abstract}

${ }^{88}$ FOUCHARD, Philippe et al.. Op. cit., p. 301-302 
been joined to the arbitration proceedings without the consent of the first defendant, which the latter was not ready to give. Consequently, any offers made by the second defendant that the claim against him should be subject to an arbitration were a nullity because they were incapable of being given effect. Any consent or concurrence by the claimant to arbitration against the second defendant would therefore be void." 89

\section{Por outro lado, cumpre trazer à colação decisão que aceitou a} consolidação da jurisdição entre cláusulas de arbitragem semelhantes.

Observe-se abaixo o caso Kis France:

"Kis France, the manufacturer of new equipment for the quick development and printing of photographs, had set up a system with Société Générale to permit the marketing of this equipment in various countries, including the United States, under the form of leasing and through their respective local subsidiaries. Various conventions had been signed (...). The framework agreement contained an ICC arbitration clause to which an express reference was made in the local agreements and the addenda. Arbitration was initiated by Société Générale, Sogelease Pacific and Sogelease Corporation, two subsidiaries of Société Générale against Kis France, Kis Photo Industrie [subsidiary of Kis USA] and Kis Corporation [subsidiary of Kis France]. The arbitral tribunal considered that it had jurisdiction over all claimants and respondents, as well as jurisdiction to decide all the issues arising under the various agreements. An action to set aside was filed with the Paris Court of Appeals which confirmed the arbitrators' jurisdiction. According to the Court of Appeals:

The Local Agreement, concluded by the subsidiaries of Société Générale and Kis France, refers to this arbitration clause. We infer from this reference that the arbitrators may decide the disputes concerning the execution of both the Basic and the Local Agreement, but only upon request of the two parent companies. The position of the subsidiaries in this sense is totally subordinate.

In granting the claim filed by Société Générale and its subsidiaries against Kis France and Kis Photo, the arbitrators examined the agreements between the parties and held that the parties' mutual obligations were inexorably linked and that the parent companies played a dominant role vis-à-vis their subsidiaries, which were bound to abide by the former's commercial and financial decisions.

The arbitrators inferred from the contractual relationships between the two groups of companies that there was a common intention of the parties to consider Kis France and Kis Photo liable for any amounts owed by them or their subsidiary Kis

\footnotetext{
${ }^{89}$ HANOTIAU, Bernard. Op. cit., p. 109-110.
} 
Corporation. Hence, the arbitrators deemed that the claim filed by Société Générale and its subsidiaries was admissible."${ }^{.90}$

Em oposição ao segundo caso citado por Fouchard, Gaillard e Goldman, é importante destacar que a doutrina não é pacífica quanto ao tema. Há corrente contrária no sentido de que devido à natureza contratual da arbitragem, o árbitro não tem todos os poderes de um juiz. Na ausência de um acordo entre as partes, o tribunal ou a instituição que administra o procedimento não seriam legitimados a consolidar diferentes procedimentos arbitrais. ${ }^{91}$

Prosseguindo na análise do segundo caso, Fouchard, Gaillard e Goldman asseveram que:

\begin{abstract}
"The problem is aggravated where the arbitration clause differs from one contract to another. (...) In order to avoid two or more tribunals reaching conflicting decisions, one might be tempted to conclude that the better solution would be to appoint a single arbitral tribunal, or to consolidate the two or more arbitrations. (...) In the absence of an agreement between the parties, neither the arbitral institution, nor the arbitral tribunal constituted on the basis of one or other of the arbitration clauses, will be entitled to resolve the whole dispute. Only where both arbitrations take place in a jurisdiction in which the courts are entitled to consolidate related actions, such as Netherlands or where two proceedings refer to the same arbitration rules allowing consolidation, will be possible to avoid the difficulties associated with having separate arbitral tribunals without further exploring the true intentions of the parties. Otherwise, if an award were made on the basis of the arbitration clause contained in one contract, but concerned issues found in another contract, the decision of the arbitral tribunal could be challenged on the basis that the tribunal ruled, at least in part, in the absence of an arbitration agreement. For the same reasons, where a contract containing a clause attributing jurisdiction to the courts is related to another contract containing an arbitration clause, there can be no extension of the arbitration clause to the first contract." ${ }^{, 92}$
\end{abstract}

\footnotetext{
${ }^{90}$ Ibid. p. 112-113.

${ }^{91}$ Confira-se a lição de: HANOTIAU, Bernard. Op. cit., p. 107.

${ }^{92}$ FOUCHARD, Philippe et al.. Op. cit., p. 303-304.
} 
Os autores supracitados apresentam como exemplo de decisão em sede arbitral, acerca da (im)possibilidade de extensão da cláusula de arbitragem a outro contrato que continha cláusula de foro, o ICC Case $\mathrm{N}^{\circ}$ 4392. No referido caso, segundo eles:

\begin{abstract}
"[the award] rightly refused to extend the scope of an arbitration clause contained in heads of agreement to a related agreement, on the grounds that the related contract reffered to general condititons of sale which included a clause attributing jurisdiction to the courts. The arbitral tribunal considered that, irrespective of any implied acceptance of the condititons by the purchaser, the buyer's intention was clearly incompatible with the extension of the arbitration agreement and had to be complied with." 93
\end{abstract}

A terceira e última situação a ser considerada em relação aos contratos que possuem a mesma finalidade diz respeito à situação em que existem contratos que possuem cláusulas compromissórias, enquanto outros não possuem nenhuma cláusula de resolução de conflitos. Para Fouchard, Gaillard e Goldman:

"once again, the problem should be addresed by interpreting the parties' intentions. Provided that the circumstances reveal that the parties intended, at least implicitly, to empower the arbitral tribunal to resolve all disputes arising out of a single group of contracts, then the tribunal shall have jurisdiction to do so." ${ }^{94}$

Referidos autores citam exemplos de decisões da Corte de Apelação de Paris e do Corte de Cassação francesa. Observe-se abaixo:

"The Paris Court of Appeals reached this conclusion in the case of an employment contract annexed to a protocol which had been signed during the sale of a company and which contained an arbitration clause. The French Cour de cassation also allowed an arbitration clause to be extended from one contract to a second aimed at formalizing the existing agreement between the parties" 95

\footnotetext{
${ }^{93}$ Ibid. p. 304.

${ }^{94}$ Ibid. p. 304.

95 Ibid. p. 304.
} 
A teoria do "group of contracts", como se pode perceber, apresenta peculiariedades de acordo com as espécies de cláusulas envolvidas. Assim, é necessário analisar a disputa em questão, para que se verifique a real intenção das partes e se é possível a extensão dos efeitos da cláusula de arbitragem para aquelas partes que não assinaram a referida cláusula. 


\section{Capítulo 3 - A extensão dos efeitos da cláusula de arbitragem para partes não signatárias à luz do Direito brasileiro}

Depois de examinar a extensão dos efeitos da cláusula de arbitragem para partes não signatárias no Direito comparado, cumpre analisar a possibilidade da referida extensão em nosso ordenamento jurídico. Será possível, à luz do Direito brasileiro, incluir no procedimento arbitral partes que não assinaram a cláusula compromissória?

Para tentar responder a esta pergunta, abordar-se-á os seguintes argumentos: a desconsideração da personalidade jurídica, o consentimento tácito e o "leading case" Trelleborg, os contratos conexos e a tutela externa do crédito.

\subsection{A teoria da Desconsideração da Personalidade Jurídica}

A teoria da desconsideração da personalidade jurídica originou-se das teorias debatidas no capítulo 2 - "piercing the corporate veil", "alter ego" e "disregard of legal entity". Em nosso ordenamento, Rubens Requião definiu bem o instituto ao lecionar que desconsiderar a personalidade jurídica seria "não considerar os efeitos da personificação, para atingir a responsabilidade dos sócios" ${ }^{96}$.

\footnotetext{
${ }^{96}$ REQUIÃO, Rubens. Curso de Direito Comercial. 27ª ed. São Paulo: Saraiva, 2007. p. 392.
} 
Referida teoria suscitou acalorado debate doutrinário, no qual a corrente subjetiva, capitaneada por Rubens Requião, prevaleceu em nossa doutrina e jurisprudência. ${ }^{97}$

Gustavo Tepedino aduz que a corrente subjetiva:

"exige como requisito para a desconsideração da personalidade jurídica a demonstração de fraude (no sentido de descumprimento ostensivo da lei, embora sob a aparência de seu cumprimento) ou abuso de direito (ou seja, utilização da pessoa jurídica para fins pessoais, verificando-se confusão entre a pessoa dos sócios e a pessoa jurídica, em autêntico desvio de finalidade do objeto social). Em outras palavras, de acordo com esta parte da doutrina, para que se desconsidere a personalidade jurídica, exige-se a demonstração de fatos atribuíveis ao sócio ou administrador que frustrem legítimo interesse do credor mediante a manipulação fraudulenta da pessoa jurídica" 98

Dito isso, cumpre destacar a positivação da teoria da desconsideração da personalidade jurídica no ordenamento brasileiro, para analisar, logo depois, a viabilidade da teoria supra ser apta a estender os efeitos da cláusula de arbitragem para partes não signatárias.

A positivação da desconsideração da personalidade jurídica no ordenamento brasileiro se deu, inicialmente, no Código de Defesa do Consumidor, em seu art. 28. Confira-se abaixo o aludido dispositivo:

“O juiz poderá desconsiderar a personalidade jurídica da sociedade quando, em detrimento do consumidor, houver abuso de direito, excesso de poder, infração da lei, fato ou ato ilícito ou violação dos estatutos ou contrato social. A desconsideração também será efetivada quando houver falência, estado de

\footnotetext{
${ }^{97} \mathrm{~A}$ teoria objetiva,por sua vez, traduz a noção de que o verdadeiro critério para se aferir a desconsideração da personalidade jurídica consiste na interpretação funcional do instituto, não se exigindo a fraude ou o abuso de direito - como pretende a teoria subjetiva - pois que estes últimos não abarcariam inúmeras situações nas quais a ineficácia da separação patrimonial ocorre em benefício do controlador sem que se caracterize abuso de direito ou fraude. Para mais informações sobre a teoria objetiva: COMPARATO, Fábio Konder; SALOMÃO, Calixto. O Poder de Controle na Sociedade Anônima. $4^{\mathrm{a}}$ ed. Rio de Janeiro: Forense, 2005.

${ }^{98}$ TEPEDINO, Gustavo. Notas sobre a Desconsideração da Personalidade Jurídica. In: TEPEDINO, Gustavo; FACHIN, Luiz Edson (Orgs.). Diálogos Sobre Direito Civil. v. II. Rio de Janeiro: Renovar, 2008. p. 9.
} 
insolvência, encerramento ou inatividade da pessoa jurídica provocados por má administração.

$\S 1^{\circ}$ (VETADO)

$\S 2^{\circ}$ As sociedades integrantes dos grupos societários e as sociedades controladas, são subsidiariamente responsáveis pelas obrigações decorrentes deste Código.

$\S 3^{\circ}$ As sociedades consorciadas são solidariamente responsáveis pelas obrigações decorrentes deste Código.

$\S 4^{\circ}$ As sociedades coligadas só responderão por culpa.

$\S 5^{\circ}$ Também poderá ser desconsiderada a pessoa jurídica sempre que sua personalidade for, de alguma forma, obstáculo ao ressarcimento de prejuízos causados aos consumidores"

Tal diploma legal gerou grande divergência na doutrina, em virtude do conflito entre a redação do caput e do parágrafo quinto. No caput se afirma que a desconsideração da personalidade jurídica somente ocorrerá se preenchidos determinados pressupostos. Todavia, no parágrafo quinto, poder-se-ia desconsiderar a personalidade jurídica sempre que essa for, de alguma forma, obstáculo ao ressarcimento de prejuízos causados aos consumidores. O parágrafo quinto adotou, assim como a legislação ambiental" ${ }^{99}$, a chamada "teoria menor".

A “teoria menor" da desconsideração contrapõe-se à denominada “teoria maior", segundo Gustavo Tepedino:

"de acordo com a qual somente nas hipóteses excepcionais de fraude, abuso ou confusão patrimonial se admite a desconsideração da personalidade jurídica, que, portanto, não se opera diante da mera insolvência ou falência da sociedade." 100

Frise-se, entretanto, que até hoje não há posicionamento consolidado sobre qual teoria prevalece. À guisa de ilustração, observe-se o caso do Osasco Plaza Shopping, no qual o Ministério Público ajuizou ação civil pública em face da sociedade e de seus administradores, objetivando o ressarcimento das vítimas de acidente ocorrido em 1996. O caso chegou ao STJ, onde os ministros da Turma Julgadora divergiram quanto ao assunto.

\footnotetext{
${ }^{99}$ Art. $4^{\circ}$ da Lei 9.605/1998: "Poderá ser desconsiderada a pessoa jurídica sempre que sua personalidade for obstáculo ao ressarcimento de prejuízos causados ao meio ambiente."

${ }^{100}$ TEPEDINO, Gustavo. Op. cit., p. 17.
} 
No caso, o relator posicionou-se no sentido de não ser possível desconsiderar a personalidade jurídica da sociedade, como se pode observar de excerto de seu voto, in verbis:

\begin{abstract}
"Com efeito, sem a presença de uma dessas circunstâncias, o suporte fático do artigo 28 , caput, não se completa, e, portanto, não incide a aludida norma jurídica - nada importando que o $\S$ $5^{\circ}$ aparente que a desconsideração da pessoa jurídica possa ser mero efeito da necessidade de ressarcir os prejuízos causados aos consumidores (...). Na técnica de interpretação, o parágrafo não tem autonomia, subordinando-se aos limites do caput" ${ }^{101}$
\end{abstract}

Contudo, a Turma Julgadora, por maioria, entendeu pela desconsideração da personalidade jurídica da sociedade para que fossem ressarcidos os danos provocados aos consumidores, em razão do desabamento de parte da estrutura, sem que houvesse ocorrido abuso da personalidade. A esse respeito, confira-se trecho da ementa do voto vencedor da Ministra Nancy Andrighi:

\begin{abstract}
"A tese, ora acolhida, de que a teoria menor da desconsideração aplica-se às relações de consumo, está calcada na exegese autônoma do $\S 5^{\circ}$ do art. 28, do CDC. (...) O referido dispositivo do CDC, quanto à sua aplicação, como bem ressaltado pelo i. Min. Relator, sugere uma "circunstância objetiva". Da exegese do $\S 5^{\circ}$ deflui, expressamente, a possibilidade de desconsideração da personalidade jurídica pela mera prova da insolvência da pessoa jurídica, fato este suficiente a causar 'obstáculo ao ressarcimento de prejuízos causados aos consumidores'.",102
\end{abstract}

Não obstante o tema no âmbito das relações de consumo se afigure ainda passível de discussão, o Código Civil de 2002 autorizou a desconsideração da personalidade jurídica em seu art. 50. Veja-se abaixo o mencionado artigo:

"Em caso de abuso da personalidade jurídica, caracterizado pelo desvio de finalidade, ou pela confusão patrimonial, pode o juiz

\footnotetext{
${ }^{101}$ STJ, Resp. n. 279.273, Rel. Ministro Ari Pargendler, Rel. para Acórdão Ministra Nancy Andrighi, Brasília, 04 dez. 2003.

${ }^{102}$ Ibid.
} 
decidir, a requerimento da parte, ou do Ministério Público quando lhe couber intervir no processo, que os efeitos de certas e determinadas relações de obrigações sejam estendidos aos bens particulares dos administradores ou sócios da pessoa jurídica."

Como se pode perceber da redação do Código Civil, a doutrina aduz que somente é possível, de acordo com o referido diploma legal, desconsiderar a pessoa jurídica, atingindo o patrimônio do administrador ou do sócio que praticou o ato fraudulento, através do controle judicial. Ressalte-se, contudo, que é imperativo que haja demonstração de fraude, abuso de direito ou confusão patrimonial. ${ }^{103}$

Após a análise de algumas hipóteses legais acerca do instituto em nosso ordenamento jurídico, ${ }^{104}$ cumpre examinar a possibilidade de se aplicar a desconsideração da personalidade jurídica para se estender os efeitos da cláusula compromissória à partes não signatárias..

O assunto também gera polêmica, como se verá a seguir. Parte da doutrina $^{105}$ entende que o novo Código Civil, em seu art. 50, admite a possibilidade de o juiz, e também o árbitro, decidir, quando provocado, que os efeitos de determinadas obrigações sejam estendidos aos bens particulares dos sócios ou administradores da pessoa jurídica, na hipótese de abuso da personalidade jurídica, caracterizada pelo desvio de finalidade ou pela confusão patrimonial. Assim, o árbitro, em princípio, poderia, se provocado, desconsiderar a personalidade jurídica da parte não signatária.

Todavia, há corrente doutrinária em sentido contrário, a qual sustenta que mesmo que o árbitro perceba confusão patrimonial entre sociedades do

\footnotetext{
${ }^{103}$ Nesse sentido: TEPEDINO, Gustavo. Op. cit., p. 21-22.

${ }^{104}$ Frise-se que também se previu a desconsideração da personalidade jurídica no art. 18 da Lei $8.884 / 1994$, a chamada lei antitruste.

105 Confira-se nesse sentido: WALD, Arnoldo. A arbitragem, os Grupos Societários e os Conjuntos de Contratos Conexos. Revista de Arbitragem e Mediação. São Paulo, v. 2, p. 57, mai./ago. 2004.
} 
mesmo grupo, não seria possível a inclusão no procedimento arbitral de sociedade que não tenha celebrado a cláusula compromissória. Assim, a desconsideração da personalidade jurídica não poderia ser manejada pelo árbitro, pois a sua jurisdição estaria limitada naturalmente pela convenção arbitral, de forma que seria inadmissível a decisão do árbitro que envolvesse terceiro que não lhe outorgou jurisdição. ${ }^{106}$

Vê-se, portanto, que é polêmica a aplicação do instituto da desconsideração da personalidade jurídica para fundamentar a extensão dos efeitos da cláusula de arbitragem para partes não signatárias. Se se reconhece que o árbitro possui os mesmos poderes do juiz togado, ele seria, então, capaz de desconsiderar a personalidade jurídica. Porém, se se acredita que tal função se limita ao juiz estatal, não seria possível a cláusula compromissória gerar qualquer efeito à uma parte que não assinou a aludida cláusula.

\subsection{O consentimento tácito e o Caso Trelleborg}

Como visto no primeiro capítulo, a Lei de Arbitragem Brasileira exige que a cláusula compromissória seja celebrada por escrito. Todavia, referida lei nada dispõe acerca de forma ou requisito especial para a demonstração do consentimento das partes sobre aquela cláusula escrita.

Com isso em mente, cumpre frisar que o ordenamento jurídico pátrio admite que o consentimento ou a manifestação de vontade seja tácita, demonstrada por outros meios que não apenas a assinatura.

Nesse diapasão, o artigo 107 do Código Civil dispõe expressamente que: "a validade da declaração de vontade não dependerá de forma especial, senão quando a lei expressamente a exigir".

\footnotetext{
${ }^{106}$ A esse respeito, veja-se a lição de: CARMONA, Carlos Alberto. Op. cit., p. 83.
} 
Não fosse só isso, a doutrina é pacifica em admitir a manifestação de vontade tácita. Afirma-se, nesse diapasão, que o consentimento reflete a intenção da parte em adotar a arbitragem para resolver os conflitos que possam surgir de determinado negócio jurídico. O consentimento, assim, pode ser expresso ou tácito e, ainda, resultar na vinculação de terceiros que não assinaram o contrato. Restringindo-se ao campo da arbitragem, a doutrina sustenta que o consentimento pode ser inferido, no caso concreto, por força de peculiaridades na atuação e na postura do terceiro em relação ao contrato objeto do litígio arbitral. ${ }^{107}$

Saliente-se, por oportuno, as palavras de Vicente Ráo:

\begin{abstract}
"Diz-se tácita a declaração de vontade resultante de certos atos, atitudes ou comportamentos incompatíveis, segundo os casos, com certa concordância ou com certa discordância. De um modo voluntário de proceder, revelado como fato exterior, a experiência infere (facta concludentia) que aquele que o pratica, ou mantém, assim manifesta ou declara uma vontade inconciliável, por força do princípio de contradição, com uma vontade oposta. Para a sua apuração (nos casos em que a declaração tácita é admitida) basta observar-se a maneira comum e razoável de apreciação dos fatos humanos, de conformidade com o que, no respectivo meio ambiente, se considera ser a ordem normal das coisas, até se alcançar a convicção honesta de que os fatos examinados equivalem, inequivocamente, à revelação de certa vontade"108
\end{abstract}

A jurisprudência corrobora tal entendimento. O Ministro Carlos Alberto Menezes Direito, ao relatar a SEC n⿳ 856, considerou válida e suficiente a manifestação de vontade da parte em submeter-se a arbitragem, não por uma declaração expressa, mas pelo fato de que a parte não impugnou, em nenhum momento durante o procedimento arbitral, a existência de cláusula compromissória.

\footnotetext{
107 Confira-se a obra de: MARTINS, Pedro A. Batista. Arbitragem. Capacidade, Consenso e Intervenção de Terceiros: Uma Sobrevista. Disponível em http://www.batistamartins.com. Acesso em 24 out. 2010.

108 RÁO, Vicente. Ato Jurídico: noção, pressupostos, elementos essenciais e acidentais: o problema do conflito entre os elementos volitivos e a declaração. $4^{\mathrm{a}}$ ed. São Paulo: Revista dos Tribunais, 1997. p. 117.
} 
Confira-se abaixo excerto de voto do relator, in verbis:

\begin{abstract}
"A leitura da contestação revela que a argumentação desenvolvida está centrada na inexistência de concordância expressa sobre a cláusula compromissória. Mas, como demonstrado, houve inequívoca aceitação da convenção arbitral, a tanto equivale à participação da empresa requerida no processo, de acordo com carta que ela própria remeteu contendo suas razões de mérito para defender-se. Veja-se com atenção que a contestação procura desqualificar essa correspondência e sua defesa alegando que não nomeou árbitro, permanecendo 'em silêncio, exatamente porque não reconhecia sua submissão à jurisdição arbitral' (fls. 187), acrescentando que não interpôs recurso de apelação, 'mas apenas manifestou-se, por correspondência, sua não concordância com o decisum, mencionando fatos e atos culposos da recorrente, preocupandose - é lógico - em repor a verdade fática. Ora, tal manifestação não pode ser admitida - é óbvio - como interposição de apelação em seu aspecto formal' (fls. 188). Pretende a requerida raciocinar no sentido de ter sido 'induzida a erro, de forma indireta e coercitivamente, a corresponder-se com o juízo arbitral, mas o fez apenas para repor a verdade fática sem ter a intenção de recorrer da decisão' (fls 188). Com todo o respeito, essa argumentação não pode merecer prestígio. E assim é, porque a parte interessada poderia, desde que tomou conhecimento, ter impugnado a instauração do Juízo arbitral, o que levaria a não ser admitido, porquanto somente se produz se as partes estão de acordo, como, de resto, é usual" ${ }^{109}$
\end{abstract}

Assim, o consentimento tácito alinha-se ao Direito brasileiro, ademais quando se sabe que o silêncio produz efeitos jurídicos. Nesse sentido, o Código Civil, em seu artigo 111, dispõe que "o silêncio importa anuência, quando as circunstâncias ou os usos o autorizarem, e não for necessária a declaração de vontade expressa".

Nessa esteira, recorre-se mais uma vez à lição de Vicente Ráo, o qual esclarece:

"é incontestável e incontestado que o silêncio possui, na ordem jurídica, certo valor... Na realidade, o silêncio só produz efeitos jurídicos quando, devido às circunstâncias ou condições de fato que o cercam, a falta de resposta à interpelação, ato ou fatos alheios, ou seja, a abstenção, a atitude omissiva e voluntária de quem silencia induz a outra parte, como a qualquer pessoa

${ }^{109}$ STJ, SEC n. 856, Rel. Ministro Carlos Alberto Menezes Direito, Brasília, 18 mai. 2005. 
induziria, à crença legítima de haver o silente revelado, desse modo, uma vontade seguramente identificada" 110

O consentimento tácito, como forma de manifestação de vontade, também foi o fundamento utilizado no emblemático caso Trelleborg, no qual o Tribunal de Justiça de São Paulo considerou parte legítima para figurar em procedimento arbitral a sociedade que não havia assinado a cláusula arbitral.

Por ser um verdadeiro "leading case", é importante esmiuçar os detalhes do caso em comento. A empresa Anel - Empreendimentos, Participações e Agropecuária Ltda. ("Anel”) propôs ação de instituição de arbitragem em face de Trelleborg Industri AB e Trelleborg do Brasil Ltda., empresas do grupo Trelleborg. Na referida demanda, a requerente alegou, em síntese, que, na qualidade de sócia da empresa PAV - Projetos e Aplicações de Vibrotécnica e Vedação Ltda., após longa negociação com a Trelleborg Industri AB, constituiu com a Trelleborg do Brasil Ltda. uma sociedade comercial denominada Trelleborg PAV Indústria e Comércio Ltda.

Ocorre que, posteriormente, a Anel tomou conhecimento de que uma outra empresa do Grupo Trelleborg, denominada Trelleborg Holding AB, adquirira a empresa AVS Brasil Getoflex Ltda. ("AVS"). Segundo a requerente, a aquisição da AVS por empresa do mesmo grupo de sua sócia na Trelleborg PAV Indústria e Comércio Ltda. inviabilizaria os negócios desta, à medida que aquela era sua principal concorrente no Brasil.

Em razão disso, a Anel notificou as rés para dar início ao processo de dissolução da sociedade comercial que constituíram e apuração de perdas, danos e lucros cessantes, por meio de arbitragem, conforme cláusula compromissória contida nos contratos que assinou com a Trelleborg do

$\overline{{ }^{110} \text { RÁO, Vicente. Op. cit., p. 119-120. }}$ 
Brasil Ltda.. Todavida, as rés se recusaram a dar início à arbitragem, o que ensejou na acão de instituição de arbitragem perante a Justiça paulista.

Na sentença, o juiz decidiu que:

\begin{abstract}
"Apesar de a constituição da Trelleborg PAV Indústria e Comércio Ltda. e de os contratos de associação e consultoria referidos na inicial vincularem apenas a Trelleborg do Brasil Ltda. e a Anel - Empreendimentos, Participações e Agropecuária Ltda. (f.), é certo que toda negociação que culminou com a celebração dos referidos contratos contou com a participação direta da Trelleborg Industri AB. (...) Além disso, consoante anotou a autora (f.), todos os contratos que vincularam a Anel - Empreendimentos, Participações e Agropecuária Ltda. e a Trelleborg do Brasil Ltda. foram redigidos nos idiomas inglês e português, circunstância indicativa de que os negócios por elas celebrados não estavam circunscritos aos interesses das empresas sediadas no Brasil, vinculando, também, à evidência, a sócia majoritária da Trelleborg do Brasil Ltda. (...) Rejeito, pois, a preliminar de ilegitimidade de parte passiva ad causam arguida pelas rés na resposta que apresentaram a f., já que manifesta a coresponsabilidade da Trelleborg Industri $\mathrm{AB}$ pelas obrigações decorrentes dos contratos firmados entre a autora e a Trelleborg do Brasil Ltda." 111
\end{abstract}

Inconformadas, a Trelleborg do Brasil Ltda. e a Trelleborg Industri $\mathrm{AB}$ apelaram da sentença reiterando a ilegitimidade da Trelleborg Industri AB para figurar no pólo passivo da demanda.

O Tribunal de Justiça de São Paulo, por unanimidade, decidiu que tal irresginação das apelantes não prosperava. Confira-se abaixo, excerto de voto da Desembargadora Relatora Constança Gonzaga, in verbis:

"É o que se vê nos autos, em que não obstante inexistente assinatura da apelante 'Trelleborg Industri AB', é mais do que evidente, face à farta documentação existente, a relação jurídica que há entre as partes, decorrente dos negócios em comum

\footnotetext{
${ }^{111}$ Justiça de São Paulo, Ação Ordinária n. 000.01.060969-5 - 13ª Vara Cível da Comarca da Capital de São Paulo, Juiz Ademir Modesto de Souza, São Paulo, 15 mai. 2002.
} 
travados, em que se observa participação ativa da apelante 'Trelleborg Industri AB'" 112

Em comentário ao caso Trelleborg, a doutrina afirma que a aceitação da cláusula arbitral não deve ser necessariamente demonstrada pela assinatura das partes. A prova de sua existência pode ocorrer através do exame da conduta das partes em todas as etapas da relação contratual. $\mathrm{Ou}$ seja, no momento da negociação, celebração e execução do contrato ou, ainda, no próprio procedimento arbitral. ${ }^{113}$

Ante o exposto, pode-se inferir que o nosso ordenamento jurídico admite, em tese, observadas as particularidades de cada caso, que a manifestação de vontade seja tácita. ${ }^{114}$

\subsection{Contratos conexos ou coligados}

À luz do Direito brasileiro, outro argumento que poderia dar ensejo a extensão dos efeitos da cláusula de arbitragem para partes não signatárias é o dos contratos conexos ou coligados.

Francisco Marino define os contratos coligados como aqueles “contratos que, por força de disposição legal, da natureza acessória de um deles ou do conteúdo contratual (expresso ou implícito), encontram-se em relação de dependência unilateral ou recíproca". ${ }^{115}$

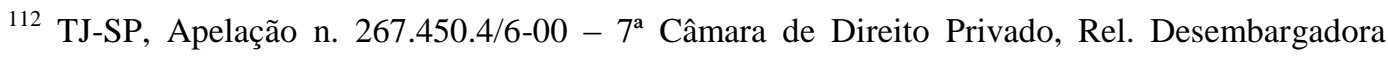
Constança Gonzaga, São Paulo, 24 mai. 2006.

${ }^{113}$ Nesse sentido: WALD, Arnoldo; GALINDEZ, Valéria. Homologação de Sentença Arbitral Estrangeira. Contrato Não Assinado. Desnecessidade de Concordância Expressa com a cláusula Compromissória. Revista de Arbitragem e Mediação. São Paulo, v. 10, p. 243-247, jul./set. 2006.

${ }^{114}$ Vale citar a lição de Flávio Pereira Lima e Daniel Calhman de Miranda, na qual se aborda que é possível que a manifestação de vontade "seja demonstrada não só pela assinatura, mas também, pela manifestação implícita, tácita, ou indireta, manifestada por meio de atos e comportamentos durante as fases de negociação, celebração e execução de um contrato, bem como durante o próprio procedimento arbitral em que a ausência de impugnação aos limites subjetivos da cláusula compromissória implicará a vinculação à mesma." (PEREIRA LIMA, Flávio; MIRANDA, Daniel Calhman. Op. cit., p. 21).

${ }_{115}$ MARINO. Francisco Paulo de Crescenso. Contratos Coligados no Direito Brasileiro. São Paulo: Saraiva, 2009. p. 99.
} 
Após a apresentação do conceito, cumpre fazer uma análise com um princípio abordado no primeiro capítulo, qual seja, o da relatividade dos contratos. Como foi demonstrado, referido princípio aduz que os efeitos do contrato se restringiriam aos contratantes, não vinculando outros. Todavia, a teoria dos contratos conexos permite que contratos diferentes, muitas vezes firmados por pessoas diferentes e de conteúdo e forma distintos, sejam interpretados em conjunto, podendo ser oponíveis a partes não signatárias.

Para que isso ocorra, a doutrina e a jurisprudência, como se verá a seguir, apontam alguns requisitos fundamentais. Além da inequívoca pluralidade de contratos, é necessário que entre os contratos em análise exista um "nexo finalístico" e uma "autonomia estrutural".

Aparentemente contraditórios, os dois elementos são complementares. Ressalte-se que os contratos coligados não são uma coisa só. Cada contrato possui sua autonomia, exercendo uma função específica dentro da operação econômica que os instrumentalizam.

Nessa esteira, cumpre trazer à baila a diferença traçada por Francisco Marino, segundo a qual:

\footnotetext{
"autonomia estrutural significa, então, que cada um dos contratos coligados conserva a própria estrutura, isto é, a própria forma (ainda que documentalmente unidos) e o próprio conteúdo. Por nexo funcional entende-se que a coligação visa a um determinado resultado econômico-social" 116
}

Adentrando um pouco mais o conceito de nexo finalístico, requisito de importância vital para a caracterização da coligação contratual, poder-seia dizer que referido nexo seria o fim contratual, o resultado ou efeito prático almejado, em conformidade com os interesses concretos das partes.

${ }^{116}$ MARINO, Francisco Paulo de Crescenzo. Op. cit., 132. 
Nesse sentido, a doutrina sustenta que são os interesses concretos das partes que determinam o nexo entre os contratos conexos, sendo certo que constituirão a essência para a sua interpreação e qualificação. ${ }^{117}$

Pois bem. Definidos os requisitos e o conceito da teoria dos contratos conexos, deve-se analisar os efeitos da coligação contratual para, depois, verificar a possibilidade de extensão dos efeitos da cláusula compromissória à partes não signatárias.

A doutrina ${ }^{118}$ entende que há basicamente três efeitos da coligação. São eles: (i) interpretação e qualificação dos contratos; (ii) validade dos contratos e (iii) eficácia dos contratos (oponibilidade).

Todavia, antes de adentrar as espécies de efeitos da coligação, é imperioso se ter em mente que os efeitos da coligação serão influenciados pela intensidade da referida coligação. Frise-se, e.g., que há casos em que os contratos podem ser coligados, por terem entre si um nexo finalístico, mas a coligação pode não ser intensa, de modo que os efeitos serão muito tímidos.

Nesse diapasão, Francisco Marino sugere alguns critérios de gradação da intensidade da coligação, dividido em dois grupos ${ }^{119}$. O primeiro grupo é o da coligação entre contratos celebrados pelas mesmas partes. Assim, quando os contratos envolvidos na coligação são firmados pelas mesmas partes, há maior propensão à produção de efeitos jurídicos.

\footnotetext{
${ }^{117}$ Veja-se a obra de Ibid. p. 133.

${ }^{118}$ Francisco Marino oferece uma classificação mais dogmática, porém menos didática. Ele divide os efeitos em cinco hipóteses: (i) interpretação, (ii) qualificação, (iii) derrogação do regime jurídico, (iv) plano da validade e (v) plano da eficácia (Ibid. p. 141-209). Konder, por sua vez, se vale de uma classificação mais genérica, porém mais didática. Ele divide os efeitos em três: (i) interpretação e qualificação, (ii) ineficácia e (iii) responsabilidade (KONDER, Carlos Nelson. Contratos Conexos: Grupos de contratos, redes contratuais e contratos coligados. Rio de Janeiro: Renovar, 2006. p. 189-272). Adota-se, para fins deste trabalho, uma versão mista da proposta de Marino com a de Konder, por ser mais didático e preciso.

${ }^{119}$ MARINO, Francisco Paulo de Crescenzo. Op. cit., p. 141-145.
} 
O segundo grupo se refere à coligação entre contratos celebrados por pessoas diferentes. Nesse grupo se insere os demais critérios de análise de intensidade da coligação contratual. São eles: (i) quando todas as partes participam do "ato de coligação" (=fechamento do negócio) e (ii) quando os contratos têm o mesmo modo de execução (prolongada ou imediata), a coligação é mais intensa.

No entanto, quando o negócio foi concluído sem a participação de terceiro, ainda que este terceiro contato guarde nexo finalístico com os demais, fazendo parte de uma mesma operação econômica, a coligação será menos intensa e pode até não gerar efeito algum. Ressalte-se, todavia, que isso não significa que em tais hipóteses não haverá coligação e efeitos daí advindos. Tudo depende do caso concreto. O que se está a discutir são apenas os indícios da menor gradação de intensidade da coligação entre os contratos.

Dito isso, é necessário analisar os efeitos "strictu sensu" da teoria dos contratos coligados. O primeiro deles é o mais intuitivo, qual seja, a interpretação e qualificação dos contratos. Deve-se fazer uma interpretação conjunta dos contratos conexos ${ }^{120}$.

Carlos Nelson Konder traz uma analogia interessante sobre o assunto ao afirmar que a coligação conduz "o olhar do intérprete da árvore isolada para perceber a floresta" ${ }^{121}$.

A jurisprudência pátria também já se posicionou sobre o tema. $\mathrm{O}$ STJ, no REsp 337.040, reconheceu expressamente a coligação entre os contratos no caso em que:

\footnotetext{
${ }^{120}$ Francisco Marino chega a afirmar que: "parece nítido que a interpretação global das cláusulas contratuais acarreta, como conseqüência lógica, a necessidade de interpretar conjuntamente os contratos coligados" (Ibid. p. 147-148).

${ }^{121}$ KONDER, Carlos Nelson. Op. cit., p. 196.
} 
"Mediante duas escrituras públicas celebradas na mesma data, A cedeu a $\mathrm{B}$ direitos sobre terrenos e casa residencial nele construída, bem como prometeu à venda dois terrenos contíguos ao primeiro. B não pagou o preço relativo aos lotes contíguos e, diante do inadimplemento, A pleiteou a resolução de ambos os contratos, alegando tratar-se de um único negócio." ${ }^{122}$

Ressalte-se que no caso não existia cláusula expressa vinculando os diferentes contratos. Não obstante, o STJ reconheceu a coligação contratual e permitiu que todo o negócio fosse desfeito.

A existência de coligação contratual pode afetar também a qualificação dos contratos envolvidos. Konder indica que a coligação pode interferir na qualificação dos contratos em análise, chamando atenção para a insuficiência do método tipológico. Como exemplo, ele indica a hipótese de um contrato de doação, que, apesar de ser gratuito, possui uma clara essência onerosa quando inserido dentro de uma operação econômica complexa. $^{123}$

O segundo efeito da coligação contratual se refere à validade dos contratos. Nesse caso, a invalidade de um contrato contamina os demais contratos coligados, de modo que os vícios de um repercutem no outro. Todavia, alguém poderia invocar, no campo da arbitragem, o princípio da autonomia da cláusula compromissória (tratada no primeiro capítulo). Lembre-se que tal princípio impõe que a cláusula arbitral é independente do contrato em que está inserida.

Diante desse impasse, a solução encontrada pela doutrina seria analisar se "o fim almejado pelas partes pode ser alcançado sem o concurso do contrato inválido". ${ }^{124}$ Caso seja possível, o contrato sobrevivente não seria afetado. Caso contrário, se a operação econômica for

\footnotetext{
${ }^{122}$ Descrição de Francisco Marino (MARINO, Francisco Paulo de Crescenzo Op. cit., p. 150-151) ao caso STJ, Resp n. 337040, Rel. Ministro Ruy Rosado de Aguiar, Brasília, 02 mai. 2002.

123 KONDER, Carlos Nelson. Op. cit. 200-201.

${ }^{124}$ MARINO, Francisco Paulo de Crescenzo Op. cit., p. 193.
} 
de todo frustrada pela invalidade de um dos contratos coligados, a invalidade afetaria toda a cadeia contratual, com a ressalva da independência da(s) cláusula(s) de arbitragem, devido ao princípio da autonomia da cláusula de arbitragem.

O terceiro efeito se refere à eficácia dos contratos (oponibilidade). Nesse ponto que o presente trabalho monográfico ganha maior relevância. Devemos perquirir a possibilidade da eficácia perante terceiros não signatários.

Segundo a doutrina, para se tornar possível esta pretensão, é necessário que o terceiro e o inadimplente compartilhem de um "interesse comum", tendo atuado de forma "concertada", que configure um "esforço comum" no evento que deu causa ao inadimplemento. ${ }^{125}$

Todavia, deve-se ter em mente as palavras de Arnoldo Wald:

\begin{abstract}
"não se trata de apurar a existência de cláusula compromissória remissiva, expressamente aceita pela nossa Lei de Arbitragem, no art. $4^{\circ}, \S 1^{\circ}$. Ter-se-á, sim, que analisar, caso a caso, para se verificar a verdadeira vontade de partes e se tal conduz à uma unicidade, inclusive econômica, da relação regida por esses diferentes contratos, sendo indivisível em vista dos efeitos que um exerce sobre o outro". ${ }^{126}$
\end{abstract}

Muito embora a doutrina aceite expressamente a extensão dos efeitos da cláusula de arbitragem para partes não signatárias, a jurisprudência diverge quanto a tal possibilidade.

Referido doutrinador comenta que:

"em recente caso CCI envolvendo unicamente empresas brasileiras em ambos os lados, o Tribunal arbitral não admitiu a extensão dos efeitos da cláusula compromissória prevista em

\footnotetext{
${ }^{125}$ A esse respeito, confira-se a lição de Ibid. p..205-209.

${ }^{126}$ WALD, Arnoldo. Op. cit., p. 55.
} 
um contrato para a resolução de litígios emergentes de outro, cuja conexão era inequívoca. Na espécie, as partes haviam assinado um primeiro contrato que continha uma convenção de arbitragem CCI e cuja validade ficara condicionada à celebração de um outro. Esta segunda avença, contudo, apesar de efetivamente firmada, contava com cláusula de eleição de foro, não admitindo, pois, a arbitragem." 127

O Tribunal de Justiça do Estado do Rio de Janeiro possui decisões conflitantes sobre a matéria. No Agravo de Instrumento $\mathrm{n}^{\circ}$ 2005.002.28435, sob relatoria do Des. Cláudio de Mello Tavares, o Tribunal entendeu que no silêncio da apólice sobre a resolução de disputas e sem que houvesse qualquer outro documento no qual se vislumbrasse a existência de uma convenção de arbitragem entre o segurador e o segurado, não podia estender ao seguro-garantia os efeitos da cláusula compromissória cujo objeto se limitava ao contrato de arrendamento. ${ }^{128}$

Em sentido contrário, no Agravo de Instrumento n 2000.002.14895, o Tribunal extinguiu o processo sem resolução do mérito, pois entendeu que a matéria deveria ser dirimida em procedimento arbitral. Para tanto, deve-se ressaltar que um dos fundamentos apresentados foi o de que em virtude de todos os contratos discutidos possuírem cláusula de arbitragem e os mesmos estarem interligados, admitiu-se a legitimidade do interveniente anuente em um dos contratos para figurar como parte legítima no litígio. ${ }^{129}$

Ante o exposto neste tópico, a despeito da jurisprudência vacilante sobre a matéria, é possível a extensão dos efeitos da cláusula de arbitragem para partes não signatárias, segundo a teoria dos contratos conexos. Todavia, deve-se atentar para os requisitos da coligação contratual, os quais definirão a intensidade dos efeitos da coligação entre os contratos.

\footnotetext{
${ }^{127}$ Ibid. p. 55.

128 TJ-RJ, Agravo de Instrumento n. 2005.002.28345, Rel. Cláudio de Mello Tavares, Rio de Janeiro, 29 mar. 2006.

${ }^{129}$ TJ-RJ, Agravo de Instrumento n. 2000.002.14895, Rel. José Mota Filho, Rio de Janeiro, 10 jan. 2001 .
} 


\subsection{Tutela externa do crédito}

O último argumento que se analisa neste trabalho é a tutela externa do crédito. Antes de definir e explicar tal teoria, cumpre esclarecer que este argumento não foi discutido ainda, em sede doutrinária, para o fim específico deste trabalho monográfico, ou seja, para a extensão dos efeitos da cláusula de arbitragem para partes não signatárias. Todavia, por se relacionar com o tema e por sua relevância acadêmica, abordar-se-á a referida teoria a seguir.

Como visto, o primeiro capítulo tratou do princípio da relatividade dos contratos. Ocorre que, na nova concepção do direito contratual, um outro princípio deve ser interpretado em conjunto com o princípio da relatividade dos contratos, qual seja, o princípio da função social do contrato.

A doutrina define a função social do contrato como preceito destinado a integrar os contratos numa ordem social harmônica, que visa impedir tanto aqueles que prejudiquem a coletividade (como nos contratos de consumo) quanto os que prejudiquem ilicitamente pessoas determinadas. ${ }^{130}$

Deste modo, a ideia da função social do contato está prevista em nossa Constituição Federal, ao fixar, como um dos fundamentos da República, em seu art. $1^{\circ}$, IV, o valor social da livre iniciativa. Tal diploma legal impõe a proibição de ver o contrato como um átomo, algo que somente afeta as partes. Qualquer contrato, portanto, tem importância para toda a sociedade e essa asserção, por força da Carta Magna, faz parte, atualmente, do ordenamento positivo brasileiro.

\footnotetext{
130 Nesse sentido, confira-se: JUNQUEIRA DE AZEVEDO, Antonio. Op. cit., p. 4 e NEGREIROS, Teresa. Teoria do Contrato: Novos Paradigmas. Rio de Janeiro: Renovar, 2002. p. 244-245.
} 
Compreendeu-se, assim, que os contratos não possuem apenas função individual: são dotados de função social, como dispõe, não só a Constituição Federal, como também o art. 421 do Código Civil.

Ressalte-se, todavia, que não se está a defender que agora terceiros possam ser partes no contrato, mas, torna-se evidente que os terceiros não podem se comportar como se o contrato não existisse.

Dito isso, indaga-se: o terceiro que contribuiu para com o inadimplemento, prejudicando o credor de um contrato, pode ser responsabilizado por tal fato? A resposta nos leva ao que se tem denominado tutela externa do crédito.

A tutela externa do crédito, corolário da função social e calcada na responsabilidade civil aquiliana, tem por objetivo, possibilitar que pessoa não participante da formação do contrato, e, portanto, não sujeita às regras contratuais por força do princípio da relatividade, seja responsabilizada por nele interferir. ${ }^{131}$

Cumpre destacar que não há uma incompatibilidade entre o princípio da relatividade dos contratos e a tutela externa do crédito. A distinção é tão tênue quanto relevante. Em primeiro lugar, pois a natureza da responsabilidade de terceiro é eminentemente extracontratual. Em segundo lugar, há na relação obrigacional uma eficácia interna, que ocorre entre as partes (relatividade dos contratos), e uma eficácia externa, que ocorre entre o titular e terceiros (tutela externa do crédito).

Diante dessa face externa do contrato, é possível perceber uma irradiação externa do direito de crédito. O direito de crédito não se exaure,

\footnotetext{
${ }^{131}$ A esse respeito: ANDRADE, Gustavo Fernandes de. A interferência ilícita do terceiro na relação contratual: a tutela externa do crédito e a oponibilidade dos contratos. Rio de Janeiro: Forense, 2007. p. 89.
} 
portanto, na tradicional dicotomia absoluto-relativo que sustenta a divisão dos direitos patrimoniais. A oponibilidade aproxima o direito de crédito dos direitos reais. ${ }^{132}$

Infere-se, assim, que a lógica dos direitos reais é transposta para os direitos de crédito: o bem deve ser respeitado por todos. A obrigação deixa de ser vista como uma relação que interessa somente ao credor e ao devedor (as partes na relação jurídica), adquirindo uma relevância externa.

Definida a tutela externa do crédito, é necessário analisar como a teoria supra poderia fundamentar a extensão dos efeitos da cláusula de arbitragem para partes não signatárias.

Como dito anteriormente, a tutela externa do crédito é calcada na responsabilidade aquiliana. Sendo assim, deve-se observar certos elementos. $^{133}$

O primeiro deles é o conhecimento. Para que se configure a responsabilidade do terceiro, é imperioso que esse tenha ciência da existência de um contrato alheio. Por essa razão, o terceiro de boa-fé, que desconhece o vínculo obrigacional alheio, não pode ser responsabilizado por eventual prejuízo sofrido pela parte de uma relação que não o vincula, ainda que sejam totalmente incompatíveis as obrigações pactuadas.

Outro elemento é a ilicitude do negócio jurídico posterior. Acolher a teoria da tutela externa do crédito pode implicar em sancionar um terceiro, cuja conduta, isoladamente considerada, é ilícita.

\footnotetext{
132 Confira-se obra dos autores: PINHEIRO, Rosalice Fidalgo; GLITZ, Frederico Eduardo Zenedin. A tutela externa do crédito e a função social do contrato: possibilidades do caso "Zeca Pagodinho". In: TEPEDINO, Gustavo; FACHIN, Luiz Edson (Orgs.). Diálogos sobre Direito Civil. v. 2. Rio de Janeiro: Renovar, 2008. p. 336-337.

${ }^{133}$ Elementos extraídos de ANDRADE, Gustavo Fernandes de. Op. cit., p. 100-104.
} 
Um terceiro elemento é o dolo. Há também a vinculação de terceiro quando esse, mediante ardil ou falsas afirmações induz, mediante ato doloso, a parte de um contrato a descumprir suas obrigações. Nesse sentido, o art. 148 do Código Civil é expresso ao dispor que:

\footnotetext{
"Pode também ser anulado o negócio jurídico por dolo de terceiro, se a parte a quem aproveite dele tivesse ou devesse ter conhecimento; em caso contrário, ainda que subsista o negócio jurídico, o terceiro responderá por todas as perdas e danos da parte a quem ludibriou."
}

O quarto e último requisito seria o propósito de causar dano. Incidirá tal requisito sempre que a celebração de um contrato posterior, incompatível com um contrato prévio, não se puder justificar, em um exame objetivo, salvo pelo propósito de causar prejuízo ao credor inocente. Nesse caso, restará configurado a lesão ao crédito, o que acarretará responsabilidade aquiliana.

Assim, percebe-se que a teoria da tutela externa do crédito exige (i) a ciência de que o negócio jurídico que se pretende firmar é, de fato, incompatível com outro que lhe antecede; (ii) que o propósito dos contratantes seja mediata ou imediatamente considerado ilícito; ou (iii) que o terceiro tenha agido dolosamente para persuadir um dos contratantes a inadimplir a obrigação já pactuada; ou ainda (iv) que o negócio jurídico tenha sido celebrado com o propósito de causar dano ao contratante inocente.

Com estes requisitos em mente, destaque-se que a doutrina costuma apontar duas situações nas quais é possível invocar a tutela externa do crédito: (i) quando um terceiro instiga o devedor a não cumprir com a sua obrigação, ou seja, a indução ao inadimplemento de negócio jurídico alheio; e (ii) quando um terceiro celebra com o devedor um contrato 
incompatível com o adimplemento da obrigação assumida perante o credor. $^{134}$

Em relação ao primeiro caso, poder-se-ia citar como exemplo o art. 608 do Código Civil. Um terceiro, e.g., convence o devedor vinculado a um pacto de não concorrência, a violar tal pacto, exercendo uma atividade concorrente, coberta por um nome alheio.

No que tange à segunda hipótese, insta trazer à baila o paradigmático “caso Zeca Pagodinho" ${ }^{135}$. Por sua importância, se faz necessário analisar os fatos do caso. A fabricante de cerveja Primo Schincariol Indústria de Cervejas e Refrigerantes S.A. ("Nova Schin”) obteve liminar em medida cautelar preparatória para impedir a veiculação da campanha publicitária da Companhia de Bebidas das Américas ("Ambev").

O juízo da $27^{a}$ Vara Cível da Comarca da Capital de São Paulo concedeu liminar na qual obrigava não somente o cantor Zeca Pagodinho e a sociedade JGS Produções Artísticas a respeitar a cláusula de exclusividade constante do contrato que haviam celebrado com a Nova Schin como também a Ambev.

Explica-se. Referido contrato dispunha que o cantor deveria se abster de participar de campanhas publicitárias ou fazer alusão a outras marcas de cerveja, sob pena de incidência de multa diária no valor de quinhentos mil reais.

\footnotetext{
${ }^{134}$ NORONHA, Fernando. Direito das obrigações: Fundamentos do Direito das Obrigações. Introdução à responsabilidade civil. v. 1. São Paulo: Saraiva, 2003. p. 463.

${ }_{135}$ Informações dos fatos do caso retiradas do TJ-SP, Agravo de Instrumento ${ }^{\circ}{ }^{346.328 .4 / 5}$, Rel. Roberto Mortari, São Paulo, 31 mar. 2004.
} 
Todavia, após participar de anúncio publicitário da Nova Schin, o cantor Zeca Pagodinho estrelou campanha publicitária da cerveja Brahma. A título de ilustração, o cantor entoou os seguintes versos: "Fui provar outro sabor, eu sei. Mas não largo meu amor, voltei" ${ }^{136}$.

Desse modo, a Nova Schin incluiu no pólo passivo da demanda a cervejaria Ambev, para que esta empresa observasse a cláusula de exclusividade pactuada entre o cantor e a Nova Schin.

Diante da decisão que concedeu a liminar, tanto a Nova Schin como a Ambev recorreram. A primeira buscava a elevação da multa diária, enquanto a segunda a exclusão. O Tribunal de Justiça de São Paulo ${ }^{137}$, a despeito de não fazer referência expressa à figura da tutela externa do crédito, entendeu que a campanha publicitária seria abusiva, reconhecendo a responsabilidade do terceiro, a Ambev, por quebra de contrato.

Após a análise da incidência da teoria da tutela externa do crédito, pode-se, por meio do método dedutivo tecer observações em relação a este trabalho monográfico.

Como visto, no caso Zeca Pagodinho, se o contrato entre a Nova Schin e o cantor apresentasse uma cláusula de arbitragem, seria possível a Nova Schin buscar a reparação do dano em face da Brahma (terceiro), por meio de procedimento arbitral. Para tanto, a invocação da tutela externa do crédito poderia justificar a permanência da Ambev no pólo passivo da arbitragem.

A Ambev, ao exercer a sua liberdade de contratar, celebrou um contrato com o cantor Zeca Pagodinho incompatível com o contrato que ele

\footnotetext{
${ }^{136}$ Ibid.

${ }^{137}$ Ibid.
} 
mantinha com a Nova Schin, inadimplindo a obrigação de exclusividade pactuada entre as partes.

Judith Martins Costa ao comentar o caso aduziu que

"o novo Código Civil, ao condicionar a liberdade contratual à função social do contrato (art. 421) e ao impor aos contratantes o dever de lealdade, derivado da boa-fé (art. 422), sinaliza no mesmo sentido: contra a razão cínica está a razão jurídica, protetora da vida civil, vale dizer, civilizada. É que o "ser civil" existe na comunidade, na dimensão supra-individual ou transubjetiva. No 'caso Zeca Pagodinho' foi essa a dimensão atingida. A técnica (jurídica), aliada à ética (dos princípios do Código Civil), pode dar outro rumo ao já tristemente célebre caso" $^{\text {"138 }}$

Assim, a tutela externa do crédito poderia servir de ferramenta para a extensão dos efeitos da cláusula de arbitragem, nas hipóteses em que terceiros (não signatários), intencionalmente, dificultam ou impossibilitam o cumprimento de uma obrigação contratual.

${ }^{138}$ MARTINS COSTA, Judith. Zeca Pagodinho, a razão cínica e o novo Código Civil Brasileiro. Disponível em http://www.voxnews.com.br/dados artigos.asp?CodArt=141. Acesso em 31 out. 2010. 


\section{CONCLUSÃO}

Neste trabalho, aborda-se a possibilidade da extensão dos efeitos da cláusula de arbitragem para partes não signatárias. Há três capítulos nos quais se busca argumentos e teorias que, dialeticamente, indiquem se seria possível atingir partes que não assinaram uma cláusula compromissória.

O primeiro capítulo trata da regra geral, ou seja, a não extensão dos efeitos da cláusula arbitral para partes não signatárias. Analisa-se, para tanto, o princípio da relatividade dos contratos, a necessidade da cláusula se arbitragem ser celebrado por escrito, e, no final, o requisito do consentimento das partes.

O segundo capítulo aborda a possibilidade de extensão dos efeitos da cláusula compromissória no Direito comparado, com ênfase no Direito francês e no Direito Americano (representativos das principais tradições jurídicas contemporâneas, quais sejam, a civil law e a common law, respectivamente). O enfoque é na teoria do "group of companies", a qual engloba a doutrina do "alter ego", "piercing the corporate veil" ou "disregard of legal entity" e o caso Dow Chemical, na teoria do "implied consent" e na teoria do "group of contracts" ou "contratos coligados'.

O terceiro e último capítulo versa acerca da questão da extensão dos efeitos da cláusula de arbitragem para partes não signatárias à luz do Direito brasileiro. Aborda-se, para tanto, a desconsideração da personalidade jurídica, o consentimento tácito e o "leading case" Trelleborg, os contratos conexos e a tutela externa do crédito.

Como se pôde perceber, é possível estender os efeitos da cláusula compromissória. Todavia, é imperioso que se observe todos os detalhes do caso concreto. Apenas os fatos serão capazes de indicar se alguma empresa 
do grupo consentiu tacitamente em levar a disputa para a arbitragem, se há contratos que guardam conexão com a disputa, se alguma das partes agiu de forma dolosa ou ilícita, etc.

Assim, pode-se concluir que se o não signatário agiu como se realmente fosse parte no contrato, a despeito de não ser formalmente integrante da avença, ele poderá ser incluído no procedimento arbitral.

Ressalte-se, entretanto, que apenas analisando exaustivamente todos os fatos, é que será possível determinar a possibilidade da extensão dos efeitos da cláusula compromissória para partes não signatárias.

Repita-se que estender os efeitos da cláusula arbitral é a exceção, e não, a regra. Para que se proceda a tal ato, os árbitros e até mesmo os juízes (quando a disputa for levada ao Poder Judiciário) devem levar em conta não apenas a lei, a vontade das partes e o contrato. Devem ter em mente, também, um antigo ditado, o qual dispunha que "cautela e caldo de galinha não fazem mal a ninguém”. É necessária extrema cautela ao se estender os efeitos da cláusula compromissória, para não se trazer para a arbitragem uma parte que não deveria figurar em tal disputa. 


\section{BIBLIOGRAFIA}

ALVES, Rafael Francisco. Clássicos da Arbitragem. Corte Internacional de Arbitragem da CCI - Sentença Parcial no 4.131, de 23 de setembro de 1982 Dow Chemical v. Isover Saint Gobain. Revista Brasileira de Arbitragem. São Paulo, n. 20, out./dez. 2008.

ANDRADE, Gustavo Fernandes de. A interferência ilícita do terceiro na relação contratual: a tutela externa do crédito e a oponibilidade dos contratos. Revista Forense. Rio de Janeiro, v. 391, p. 89-110, 2007.

BARBOSA MOREIRA, José Carlos. Unidade ou Pluralidade de contratos: contratos conexos, vinculados ou coligados. Litisconsórcio necessário e litisconsórcio facultativo. 'Comunhão de interesses', 'conexão de causas' e 'afinidade de questões por um ponto comum de fato ou de direito'. Revista dos Tribunais. São Paulo, v. 817, p. 753-762, 2003.

BLACKABY, Nigel et. al.. Redfern and Hunter on International Arbitration. Student Version. Fifth Edition. Oxford: Oxford University Press, 2009. 727p.

BORN, Gary B. International Commercial Arbitration. v. I. Alphen aan den Rijn: Kluwer Law International, 2009. 1738p.

CARMONA, Carlos Alberto. Arbitragem e Processo: Um comentário à Lei no 9.307/96. $3^{\text {a }}$ Edição. São Paulo: Editora Atlas, 2009. 571p.

COMPARATO, Fábio Konder; SALOMÃO, Calixto. O Poder de Controle na Sociedade Anônima. $4^{\mathrm{a}}$ ed. Rio de Janeiro: Forense, 2005. 597p.

Corte Internacional de Justiça, Presid. M. Bustamante y Rivero, Haia, fev. 1970. Disponível em http://www.icj-cij.org/docket/files/50/5387.pdf. Acesso em 01 nov. 2010.

DAVIES, Paul L. Gower and Davies' Principles of Modern Company Law. Eighth Edition. London: Sweet \& Maxwell Ltd, 2008. 1258p.

EASTERBROOK, Frank H; FISCHEL, Daniel R. Corporate Practice Commentator. Limited Liability Corporation. University of Chicago Law Review. Chicago, n. 52, p.01-89, 1985.

EISENBERG, Melvin Aron. Corporations and Other Business Organizations: Cases and Materials. Ninth Edition. New York: Foundation Press, 2005. 1403p. 
FOUCHARD, Philippe et al.. Fouchard Gaillard Goldman on International Commercial Arbitration. The Hague: Kluwer Law International, 1999. 1280p.

FOX, Charles M. Working with Contracts: What Law School Doesn't Teach You. New York City: Practising Law Institute, 2002. 312p.

GARNER, Bryan A. (editor in chief). Black's Law Dictionary. Eighth Edition. Dallas: Thomson West, 2004. p.1810.

GOMES, Orlando. Contratos. 26ª ed. Rio de Janeiro: Forense, 2007. 627p.

HANOTIAU, Bernard. Complex Arbitrations: Multiparty, Multicontract, Multi-issue and Class Actions. The Hague: Kluwer Law International, 2005. 393p.

HENRIQUES, Andréia. Judiciário - Arbitragem cresce 10\% ao ano e ganha espaço nas empresas. Disponível em http://www.conima.org.br/informativo/info03/. Acesso em 01 nov. 2010.

JUNQUEIRA DE AZEVEDO, Antônio. Revista dos Tribunais. Princípios do Novo Direito Contratual e Desregulamentação do Mercado - Direito de Exclusividade nas Relações Contratuais de Fornecimento - Função Social do Contrato e Responsabilidade Aquiliana do Terceiro que Contribui para Inadimplemento Contratual. Revista dos Tribunais. São Paulo, n. 750, p.113-119, abr.1998.

Justiça de São Paulo, Ação Ordinária n. 000.01.060969-5 - 13 ${ }^{\text {a }}$ Vara Cível da Comarca da Capital de São Paulo, Juiz Ademir Modesto de Souza, São Paulo, 15 mai. 2002.

KONDER, Carlos Nelson. Contratos Conexos: Grupos de contratos, redes contratuais e contratos coligados. Rio de Janeiro: Renovar, 2006. 296p.

KRAAKMAN, Reinier et al.. The Anatomy of Corporate Law: - A Comparative and Functional Approach. Second Edition. Oxford: Oxford University Press, 2009. 322p.

LORENZETTI, Ricardo. Redes contractuales: conceptualización jurídica, relaciones internas de colaboración, efectos frente a terceros. Revista de Direito do Consumidor. São Paulo, n. 8, out./dez. 1998.

MARINO. Francisco Paulo de Crescenzo. Contratos Coligados no Direito Brasileiro. São Paulo: Saraiva, 2009. 246p. 
MARTINS, Pedro A. Batista. Apontamentos sobre a Lei de Arbitragem. $1^{\mathrm{a}}$ Edição. Rio de Janeiro: Forense, 2008. 447p.

MARTINS, Pedro A. Batista. Arbitragem. Capacidade, Consenso e Intervenção de Terceiros: Uma Sobrevista. Disponível em http://www.batistamartins.com. Acesso em 24 out. 2010.

MARTINS, Pedro A. Batista. Autonomia da cláusula compromissória. Disponível em <http://www.batistamartins.com/artigos>. Acesso em 01 nov. 2010.

MARTINS COSTA, Judith. Zeca Pagodinho, a razão cínica e o novo Código Civil Brasileiro. Disponível em: 〈http://www.voxnews.com.br/dados_artigos.asp?CodArt=141 >. Acesso em 31 out. 2010.

MAXIMILIANO, Carlos. Hermenêutica e aplicação do direito. Rio de Janeiro: Forense, 1996. 426p.

MAYER, Pierre. Extension of the Arbitration Clause to Non-Signatories Under French Law. In: HOUT, Tjaco T. van den (Org.). Multiple Party Actions in International Arbitration. Oxford: Oxford University Press, 2008. p. 189-199.

NEGREIROS, Teresa. Teoria do Contrato: Novos Paradigmas. Rio de Janeiro: Renovar, 2002. 544p.

NORONHA, Fernando. Direito das obrigações. Fundamentos do Direito das obrigações. Introdução à responsabilidade civil. v. 1. São Paulo: Saraiva, 2003. 698p.

PARK, William W. Non Signatories and International Contracts: an Arbitrators Dilemma. In: HOUT, Tjaco T. van den (Org.). Multiple Party Actions in International Arbitration. Oxford: Oxford University Press, 2008. p. 3-33.

PEREIRA LIMA, Flávio; MIRANDA, Daniel Calhman. Arbitragem no Brasil. A Extensão da Cláusula Compromissória a Partes não Signatárias no Direito Brasileiro. São Paulo: Impressão Régia, 2010. p. 13-25.

PINHEIRO, Rosalice Fidalgo; GLITZ, Frederico Eduardo Zenedin. A tutela externa do crédito e a função social do contrato: possibilidades do caso "Zeca Pagodinho". In: TEPEDINO, Gustavo; FACHIN, Luiz Edson (Orgs.). Diálogos sobre Direito Civil. Vol. 2. Rio de Janeiro: Renovar, 2008. p. 323-344. 
RÁO, Vicente. Ato Jurídico: noção, pressupostos, elementos essenciais e acidentais: o problema do conflito entre os elementos volitivos e a declaração. $4^{a}$ ed. São Paulo: Revista dos Tribunais, 1997. 426p.

REQUIÃO, Rubens. Curso de Direito Comercial. 27 $7^{\mathrm{a}}$ ed. São Paulo: Saraiva, 2007. 541p.

STF, SEC n. 6753-7, Rel. Mauricio Corrêa, Brasília, 13 jun. 2002.

STJ, Resp. n. 279.273, Rel. Ministro Ari Pargendler, Rel. para Acórdão Ministra Nancy Andrighi, Brasília, 04 dez. 2003.

STJ, REsp n. 337.040, Rel. Ministro Ruy Rosado de Aguiar, Brasília, 02 mai. 2002.

STJ, SEC n. 856, Rel. Ministro Carlos Alberto Menezes Direito, Brasília, 18 mai. 2005.

STJ, SEC n. 866, Rel. Ministro Felix Fischer, Brasília, 17 mai. 2006.

STJ, SEC n. 885, Rel. Francisco Falcão, Brasília, 02 ago. 2010.

STJ, SEC n. 978, Rel. Ministro Hamilton Carvalhido, Brasília, 17 dez. 2008.

STUCKI, Blaise. Extension of Arbitration Agreements to Non-Signatories. ASA Below 40 - Conference of September 29, 2006. Geneva, p.1-9.

TEPEDINO, Gustavo et al.. Código Civil interpretado: conforme a Constituição da República. v. II. Rio de Janeiro: Renovar, 2006. 909p.

TEPEDINO, Gustavo. Notas sobre a Desconsideração da Personalidade Jurídica. In: TEPEDINO, Gustavo; FACHIN, Luiz Edson (Orgs.). Diálogos Sobre Direito Civil. Vol. II. Rio de Janeiro: Renovar, 2008. p. 03-32.

TJ-RJ, Agravo de Instrumento n ${ }^{\circ}$ 07839/2003, Rel. Ademir Paulo Pimentel, Rio de Janeiro, 29 out. 2003.

TJRJ, Agravo de Instrumento n. 2000.002.14895, Rel. José Mota Filho, Rio de Janeiro, 10 jan. 2001.

TJ-RJ, Agravo de Instrumento n. 2005.002.28345, Rel. Cláudio de Mello Tavares, Rio de Janeiro, 29 mar. 2006.

TJ-RJ, Apelação Cível nº 2001.001.28808, Rel. Gilberto Rego, Rio de Janeiro, 30 abr. 2002. 
TJ-SP, Agravo de Instrumento ${ }^{\circ}$ 346.328.4/5, Rel. Roberto Mortari, São Paulo, 31 mar. 2004.

TJ-SP, Apelação n. 267.450.4/6-00 - 7 a Câmara de Direito Privado, Rel. Desembargadora Constança Gonzaga, São Paulo, 24 mai. 2006.

TOWNSEND, John M. Agency, Alter Ego and Other Identity Issues: Nonsignatories and Arbitration. ADR - The Newsletter of Dispute Resolution Law and Practice. New York City, vol. 3, n 3, set.1998.

TYLER, Timothy et al.. Beyond Consent: Applying Alter Ego and Arbitration Doctrines to Bind Sovereign Parents. In: HOUT, Tjaco T. van den (Org.). Multiple Party Actions in International Arbitration. Oxford: Oxford University Press, 2008. p. 149-188.

VILLELA, João Baptista et al. Princípios Unidroit Relativos aos Contratos Comerciais Internacionais 2004. São Paulo: Quartier Latin, 2009. 406p.

WALD, Arnoldo. A arbitragem, os Grupos Societários e os Conjuntos de Contratos Conexos. Revista de Arbitragem e Mediação. São Paulo, vol. 2, p. 31-59, mai/ago. 2004.

WALD, Arnoldo; GALINDEZ, Valéria. Homologação de Sentença Arbitral Estrangeira. Contrato Não Assinado. Desnecessidade de Concordância Expressa com a cláusula Compromissória. Revista de Arbitragem e Mediação. São Paulo, vol. 10, p. 228-246, jul./set. 2006. 